\title{
Pasientens krav på erstatning ved skade som er særlig stor eller særlig uventet
}

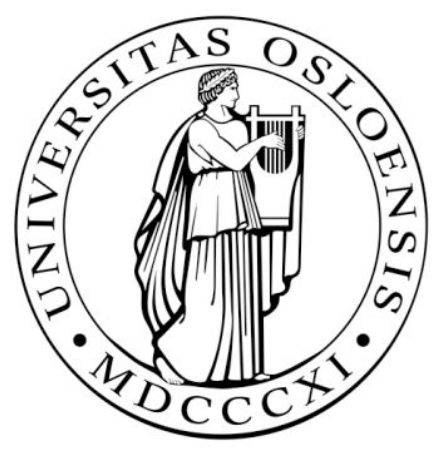

Universitetet i Oslo

Det juridiske fakultet

Kandidatnummer: 512

Leveringsfrist: $25 / 4-2010$

Til sammen 12535

22.04.2010 


\section{Innholdsfortegnelse}

1 PROBLEMSTILLING OG AVGRENSNING

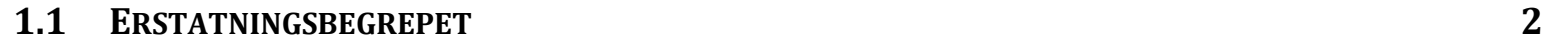

$\begin{array}{lll}1.2 & \text { HISTORIE } & 2\end{array}$

$\begin{array}{lll}1.3 & \text { FORHOLDET TIL ANNEN LOVGIVNING } & 4\end{array}$

$\begin{array}{lll}1.4 & \text { RETTSKILDEBILDET } & 4\end{array}$

$\begin{array}{lll}1.4 .1 & \text { LOV } & 4\end{array}$

1.4.2 FORARBEIDER

1.4.3 DE MIDLERTIDIGE REGLENE

1.4.4 RETTSPRAKSIS

1.4.5 PRAKSIS FRA PASIENTSKADENEMNDA 6

$\begin{array}{lll}1.4 .6 & \text { JURIDISK TEORI }\end{array}$

$\begin{array}{lll}1.4 .7 & \text { REELLE HENSYN } & 7\end{array}$

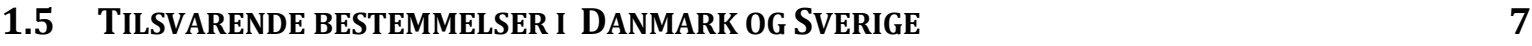

1.5.1 RIMELIGHETSREGELEN I DANMARK $\quad 8$

1.5.2 RIMELIGHETSREGELEN I SVERIGE 9

$\begin{array}{lll}1.6 & \text { FREMSTILLINGEN VIDERE } & 10\end{array}$

$\underline{2}$ PASIENTSKADELOVENS ANVENDELSESOMRÅDE M.V. 11

$\begin{array}{lll}2.1 & \text { PASIENTSKADEBEGREPET } & 11\end{array}$

$\begin{array}{lll}2.2 & \text { SKADESTED } & 12\end{array}$

$\begin{array}{lll}2.3 & \text { SKADE VOLDT AV HELSEPERSONELL } & 12\end{array}$

$\begin{array}{lll}2.4 & \text { HVEM KAN KREVE ERSTATNING? } & 12\end{array}$

$\begin{array}{lll}2.5 & \text { ANSVARSSUBJEKTET } & 13\end{array}$

$\underline{3}$ ANSVARSGRUNNLAGENE 15

$\begin{array}{lll}3.1 & \text { INNLEDNING } & 15\end{array}$

$\begin{array}{lll}3.1 .1 & \text { SVIKTREGELEN } & 15\end{array}$

3.1.2 REGLENE OM OBJEKTIVT ANSVAR 16 
$\begin{array}{lll}4.1 & \text { INNLEDNING } & 17\end{array}$

4.2 HENSYNENE BAK RIMELIGHETSREGELEN I PASIENTSKADELOVEN 18

$\begin{array}{lll}4.3 & \text { VAR RIMELIGHETSREGELEN EN NYSKAPNING? } & 19\end{array}$

4.4 UTGANGSPUNKTET VED ERSTATNING ETTER § 2 TREDJE LEDD 20

4.5 TILFELLER SOM IKKE OMFATTES AV REGELEN 20

4.6 VILKÅRENE I § 2 TREDJE LEDD

$\begin{array}{lll}4.7 & \text { SARLIG STOR PASIENTSKADE } & 21\end{array}$

$\begin{array}{lll}4.7 .1 & \text { INNLEDNING } & 21\end{array}$

4.7.2 SKADENS OMFANG I FORHOLD TIL GRUNNLIDELSEN 22

4.7.3 DANSK PRAKSIS PÅ SKADENS OMFANG I FORHOLD TIL GRUNNLIDELSE 23

4.7.4 SKADENS OMFANG I FORHOLD TIL INDIKASJON FOR INNGREPET

$\begin{array}{lll}\text { 4.7.5 DANSK PRAKSIS PÅ SKADENS OMFANG } & 27\end{array}$

4.7.6 SKADE OPPSTÅTT VED FOREBYGGENDE BEHANDLING 27

4.7.7 GRADEN AV MEDISINSK INVALIDITET 29

4.7.8 SÆRLIG STOR SKADE I FORHOLD TIL INNGREPETS STØRRELSE 31

4.8 OPPSUMMERING AV HVA SOM ER Å ANSE SOM SFRLIG STOR SKADE 32

4.9 SARLIG UVENTET PASIENTSKADE

$\begin{array}{lll}4.9 .1 & \text { INNLEDNING } & 32\end{array}$

4.9.2 SÆRLIG UVENTET I FORHOLD TIL RISIKOENS STøRRELSE 33

4.9.3 SÆRLIG UVENTET I FORHOLD TIL INFORMASJONEN SOM BLE GITT 35

4.9.4 SÆRLIG UVENTET I FORHOLD TIL INNGREPETS STøRRELSE 36

4.9.5 OPPSUMMERING AV HVA SOM ER Å ANSE SOM SÆRLIG UVENTET PASIENTSKADE 36

4.10 ER SÆRLIG STOR OG SÆRLIG UVENTET TO SELVSTENDIGE GRUNNLAG? 37

5 HVOR GÅR GRENSEN FOR RISIKO SOM MÅ AKSEPTERES?

$\begin{array}{llr}5.1 & \text { INNLEDNING } & 39\end{array}$

5.2 AKSEPTABEL RISIKO SAMMENHOLDT MED GRUNNLIDELSENS ART $\quad 40$

5.3 AKSEPTABEL RISIKO SAMMENHOLDT MED LIVREDDENDE BEHANDLING

$\begin{array}{lll}5.4 & \text { SKADEOMFANG OG UAKSEPTABEL RISIKO } & 42\end{array}$ 
6 TILSTREKKLIG INFORMASION

$\begin{array}{lll}6.1 & \text { INNLEDNING } & 43\end{array}$

6.2 HVILKE RISIKOER ER DET NERLIGGENDE Å INFORMERE OM?

6.3 ANVENDELSESOMRÅDET FOR MOMENTET TILSTREKKELIG INFORMASJON $\quad 43$

6.4 BETYDNINGEN AV TILSTREKKELIG INFORMASJON ETTER § 2 TREDJE LEDD

6.4.1 PRAKTISERINGEN AV MOMENTET $\quad 44$

6.5 OPPSUMMERING AV TILSTREKKELIG INFORMASJON 46

7 AVSLUTTENDE BETRAKTNINGER $\quad 49$

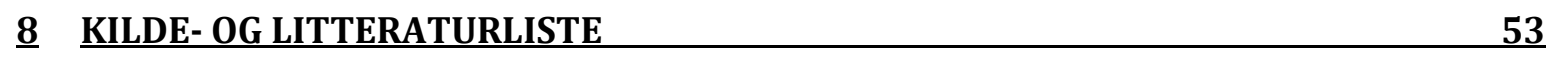

$\underline{9}$ FIGURER $\quad$ B 


\section{Problemstilling og avgrensning}

Det sentrale emnet for oppgaven er lov om erstatning ved pasientskader av 15. juni. nr. 53. 2001 (heretter pasientskadeloven) $§ 2$ tredje ledd. Regelen blir kalt en sikkerhetsventil/rimelighetsregel hvor erstatning kan tilkjennes i særlige tilfeller. Bestemmelsen tar sikte på å fange opp tilfeller hvor det vil virke støtende på rettsfølelsen å ikke tilkjenne erstatning. Eksempelvis kan regelen komme til anvendelse ved sjeldne, uunngåelige skader hvor pasientens tilstand er betydelig forverrert som følge av behandlingen. ${ }^{1}$ Den sentrale problemstillingen vil være å finne grensen på når en pasientskade er å anse som særlig stor eller særlig uventet og som ikke kan anses som utslag av en risiko som pasienten må akseptere. Regelen er ment å fange opp tilfeller der det før ble gitt billighetserstatning (nå kalt rettferdsvederlag). ${ }^{2}$

Utenfor oppgaven faller den materielle regelen ved erstatning til pasienter der det foreligger ansvarsgrunnlag etter pasientskadeloven $\S 2$ første ledd bokstav a jf $\S 2$ andre ledd, eller det objektive ansvaret i lovens $\S 2$ første ledd bokstav b, c og d, Stortingets rettferdsvederlagsordning, folketrygdens ytelser ved sykdom, skade og lyte og de prosessuelle reglene ved pasientskadeerstatning. Pasientskader som vil bli løst av produktansvarsloven blir heller ikke omtalt her.

\footnotetext{
${ }^{1}$ NOU 1992:6 s. 94 jfr. s. 77-78

${ }^{2}$ Ot.prp. nr. 31 (1998-1999) s. 91, første spalte.
} 


\subsection{Erstatningsbegrepet}

For at en pasient skal ha rett til erstatning må tre kumulative vilkår være oppfylt. Det må for det første foreligge en skade. For det andre må noen kunne holdes ansvarlig etter et ansvarsgrunnlag som kan være culpa eller objektivt ansvar. For det tredje må det foreligge adekvat årsakssammenheng mellom pasientskaden og den skadevoldende handling. Avhandlingen tar for seg de tilfeller det ikke foreligger noe tradisjonelt ansvarsgrunnlag, men hvor erstatning gis av rimelighetshensyn etter pasientskadeloven $\S 2$ tredje ledd.

\subsection{Historie}

Frem til januar 1988 kunne skadelidte rette et erstatningskrav mot skadevolder direkte etter alminnelige regler om skyldansvar (culparegelen) eller etter arbeidsgiveransvaret. Pasienten hadde som hovedregel bevisbyrden for at ansvarsgrunnlaget og årsakssammenhengen forelå og måtte bevise at legen/sykehuset hadde opptrådt uaktsomt og at det var årsakssammenheng mellom den skaden pasienten var påført og den uaktsomme opptreden. ${ }^{3}$ Det var ofte vanskelig eller umulig for pasienten å påvise ansvarsbetingende skyld hos enkeltpersoner, da helsepersonell ofte var lite villige til å medvirke til en slik oppklaring. Prosessen med å la saken gå for domstolen var kostbar og en stor belastning for pasienten, mange lot derfor være å reise erstatningskrav mot helsepersonell eller sykehus.

I en regjeringskonferanse i januar 1987 besluttet regjeringen derfor å iverksette en prøveordning som skulle gi erstatning for behandlingsskader i offentlige somatisk sykehus samt private sykehus som ble omfattet av fylkeskommunale helseplaner eller

\footnotetext{
${ }^{3}$ Arbeidsgruppens notat om erstatningsordning for pasientskader s.11
} 
fikk sine utgifter dekket over statsbudsjettet. Justisdepartementet fikk samtidig i oppdrag å utarbeide lovregler om objektivt ansvar for skader på pasienter. ${ }^{4}$

I påvente av lovregulering, ble det etablert en midlertidig erstatningsordning som ble administrert av Norsk Pasientskadeerstatning (NPE). De midlertidige reglene som trådte i kraft 1. januar 1988, var ikke gjennomført ved lov men ved avtaler mellom staten og landets fylkeskommuner som på den tiden var sykehuseier. Fra 1. juli 1992 ble den midlertidige ordningen utvidet til å gjelde for kommunelegetjenesten, kommunal legevakt, psykiatriske sykehus og deres poliklinikker. ${ }^{5}$ Forslag til pasientskadeloven (Ot.prp. nr. 31 (1998-1999)) ble lagt frem for Stortinget 18. desember 1998. Proposisjonen bygget på utredningen fra Lødruputvalget "Erstatning ved pasientskader" i NOU 1992:6. Ettersom pasientskadeloven hadde flere berøringspunkter med de fire helselovene som nylig hadde blitt vedtatt, ble det nødvendig å harmonisere begrepsbruken med de vedtatte helselovene (pasientrettighetsloven, helsepersonelloven, spesialisthelsetjenesteloven og psykisk helsevernloven). Det ble derfor fremmet et nytt samlet forslag i Ot.prp. nr. 55 (19992000) som i hovedtrekk er lik Ot.prp. nr. 31 (1998-99).

Pasientskadeloven trådte i kraft for den offentlige helsetjenesten fra 1. januar 2003. Fra 1. januar 2009 trådte loven også i kraft for den private helsetjenesten. Dette innebærer at alle pasientskader skal behandles etter de samme erstatningsreglene, uansett om skaden har skjedd i det private eller den offentlige helsetjenesten jfr. Kongelig Resolusjon 21. oktober 2008 nr. 1611.

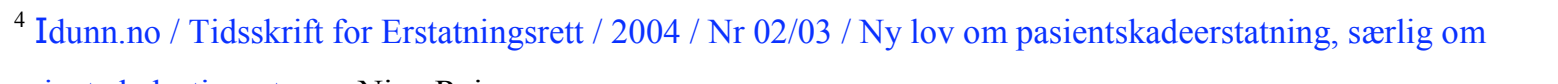
private helsetjenester av Nina Reinersen.

${ }^{5}$ Ot.prp.nr. 103 (2005-2006) side 7, første spalte.
} 


\subsection{Forholdet til annen lovgivning}

Beregning av tap følger de vanlige erstatningsrettslige reglene $\mathrm{i}$ lov om skadeserstatning av 13. juni 1969 nr. 26 jfr. pasientskadeloven $\S 4$. Ved utmåling av erstatning for personskade skal det gjøres fradrag for trygdeytelser, samt fradrag for helsemessige og sosiale tjenester og andre velferdsytelser som skadelidte får etter skadeforvoldelsen (compensatio lucri cum damno). ${ }^{6}$ Det er skadeserstatningsloven kapittel 3 om erstatning for skade på person og kapittel 5 om skadelidtes medvirkning som vil komme til anvendelse. Disse reglene vil også komme i betraktning dersom man kommer til at det skal ytes erstatning selv om det ikke foreligger ansvarsgrunnlag etter pasientskadeloven $\S 2$ første og annet ledd.

\subsection{Rettskildebildet}

\subsubsection{Lov}

Pasientskadeloven av 15. juni 2001 nr. 53 er den sentrale loven i oppgaven. Loven regulerer anvendelsesområde, hvem som er ansvarlig etter loven, saksbehandlingsregler, pasientens klageadgang, domstolsprøving og virkeområde. Loven gjelder for skader som er voldt etter lovens ikrafttredelse, eldre skader behandles etter loven, men erstatningskravet avgjøres etter de da gjeldende erstatningsregler, jfr. pasientskadeloven $\S 21$.

Pasientrettighetsloven av 2. juli 1999 nr. 63 vil være relevant ved vurderingen av hva som er å anse som tilstrekkelig informasjon etter pasientskadeloven $\S 2$ tredje ledd.

\footnotetext{
${ }^{6}$ Asbjørn Kjønstad, Erstatningsretten i utvikling s. 31
} 


\subsubsection{Forarbeider}

Ved tolkning av rimelighetsregelen i pasientskadeloven vil forarbeidene til loven være av rettskildemessig betydning. Relevante forarbeider er NOU 1992:6 "Erstatning ved pasientskader", Ot. prp. nr 31 (1998-1999), Ot. prp. nr 55 (19992000) og Innst. O. nr 68 (2000-2001), samt lovendringsforslagene fremlagt i Ot. prp. nr. 103 (2005-2006). For å se på hvor langt informasjonsplikten går er Ot. prp. nr 12 (1998-99) Om lov om pasientrettigheter, relevant.

\subsubsection{De midlertidige reglene}

Som nevnt er de midlertidige reglene om pasientskadeerstatning en relevant rettskilde. De midlertidige reglene var ikke gjennomført ved lov, men ved en avtale inngått mellom de som den gangen var eiere av de offentlige somatiske sykehusene. Forarbeidene består av arbeidsgruppens notat om pasientskadeordningen. Den midlertidige ordningen var utformet som en lov, og hadde lovs karakter. De midlertidige reglene ble tolket på samme måte som en lov, og arbeidsgruppens notat ble brukt på samme måte som alminnelige forarbeider. Arbeidsgruppens notat vil derfor være en relevant rettskilde.

\subsubsection{Rettspraksis}

Pasientskadeloven er en relativt ny lov, det finnes derfor begrenset autoritativ rettspraksis. De midlertidige reglene om pasientskadeerstatning ble praktisert i 15 år før pasientskadeloven trådte i kraft. Mange tolkningsspørsmål er derfor blitt avgjort gjennom rettspraksis fra den midlertidige ordningen. Ettersom pasientskadeloven i stor utstrekning bygger på den midlertidige ordningen for pasientskadeerstatning vil rettspraksis fra denne tiden være en relevant rettskilde og vil kunne tillegges vekt. ${ }^{7}$

\footnotetext{
${ }^{7}$ Ot.prp.nr. 31 (1998-1999) s. 5 og 63 første spalte .
} 
Høyesterett har avsagt dom i fire saker som vil være sentral for oppgaven: Rupturdommen (Rt.1998 s. 1336), Cauda equina-dommen (Rt.1998 s. 1538), Angiografidommen (Rt.2006 s. 1217) og Sarkomdommen (Rt.2008 s.218). Disse avgiørelsene omhandler blant annet rimelighetsregelen, men alle dommene ble avgjort etter de midlertidige reglene. I tillegg berøres Nervesvulstdommen (Rt. 1993 s. 1169) under behandlingen av hva som er å anse som tilstrekkelig informasjon $\mathrm{i}$ henhold til pasientskadeloven $\S 2$ tredje ledd. Det er videre inntatt noen underrettsdommer hvor den aktuelle bestemmelsen blir vurdert.

\subsubsection{Praksis fra Pasientskadenemnda}

Pasientskadenemnda (PSN) behandler klager på vedtak fattet av Norsk pasientskadeerstatning, jfr. pasientskadeloven $\S 15$. Lovgiver har tillagt Pasientskadenemndas praksis særlig betydning som rettskildefaktor, dette kommer frem av forarbeidene der det står at "Det forutsettes at domstolene vil legge vekt på Pasientskadenemndas praksis. ${ }^{\prime 8}$ Dette er også stadfestet av Høyesterett i den grad Pasientskadenemndas avgjørelse "... kan tas som uttrykk for, eller å ha gitt seg utslag i, en fast og konsistent praksis" se Rt. 2006 s.1217 (premiss 38). Praksis fra Pasientskadenemnda er derfor en relevant rettskilde og vil tillegges vekt, men mindre vekt enn rettspraksis. ${ }^{9}$

\subsubsection{Juridisk teori}

Det finnes en begrenset mengde med juridisk litteratur om rimelighetsreglen i pasientskadeerstatning. Det er skrevet noen juridiske artikler om pasientskadeloven, men ingen artikler som utelukkende omhandler rimelighetsregelen. Artikler og teori som har vært relevante for oppgaven har jeg gjengitt i litteraturlisten.

\footnotetext{
${ }^{8}$ Ot.prp.nr. 31 (1998-1999) s. 85 første spalte.

${ }^{9}$ Asbjørn Kjønstad, Helserett s. 61.
} 


\subsubsection{Reelle hensyn}

Loven åpner for å ta i betraktning reelle hensyn i pasientskadeloven $\S 2$ tredje ledd ved pasientskader som er " ... særlig stor eller særlig uventet...". At tredje ledd er en skjønnsregel kommer til uttrykk i Ot. Prp. nr. 31 "Erstatning bør ytes når det ikke er rimelig at pasienten selv bærer følgene av skaden. Hvilke tilfeller som omfattes, må bero på et konkret skjønn". ${ }^{10}$

Forarbeidene bruker begreper som "rimelighetsregelen" og "sikkerhetsventil". ${ }^{11}$ Dette gir en indikasjon på at man skal ta i betraktning resultatets godhet og alminnelige rettsoppfatninger, som er momenter med utspring fra reelle hensyn. ${ }^{12}$

\subsection{Tilsvarende bestemmelser i Danmark og Sverige}

Inspirasjonen til de nordiske pasientskadeerstatningsordningene kommer fra Sverige, hvor man allerede på 70-tallet etablerte en pasientforsikringsordning. Som følge av de positive erfaringer med pasientforsikringsordningen i Sverige fulgte de øvrige nordiske landene gradvis etter. ${ }^{13}$ Dette innebærer at den norske ordningen $\mathrm{i}$ utgangspunktet bærer preg av den svenske pasienskadeforsikringen. Jeg vil i korte trekk beskrive den danske og svenske "rimelighetsregel".

\footnotetext{
${ }^{10}$ Ot.prp. nr. 31(1998-99), s. 68 annen spalte.

${ }^{11}$ Op.cit. s. 67 annen spalte.

${ }^{12}$ Reelle hensyn som rettskilde, s. 2 av Asbjørn Kjønstad.

${ }^{13}$ Arne Grünfeld. De nordiske pasientforsikringsordninger-ligheder og forskelle. I anledning af Patientforsikringens 10 års jubilæum i 2002. s. 65.
} 


\subsubsection{Rimelighetsregelen i Danmark}

I Danmark er erstatningsbetingelsene delt opp i to hovedgrupper, de skader som kunne vært unngått og de uunngåelige skader.

Skader som kunne vært unngått [min anmærkning]:

"1) Hvis det må antages, at en erfaren specialist på det pågæ/dende område under de i øvrigt givne forhold ville have handlet anderledes ved undersoge/se, behandling el.lign., hvorved skaden ville være undgået,

2) hvis skaden skyldes fejl eller svigt i teknisk apparatur, redskaber eller andet udstyr, der anvendes ved eller i forbinde/se med undersoge/se, behandling el.lign.,

3) hvis skaden ud fra en efterfolgende vurdering kunne være undgået ved hjælp af en anden til rådighed stående behandlingsteknik eller behandlingsmetode, som ud fra et medicinsk synspunkt ville have varet lige så effektiv til behandling af patientens sygdom..."

Den danske "rimelighetsregelen" [min anmerkning]:

"4) hvis der som folge af undersogelse, herunder diagnostiske indgreb, eller behandling indtræder skade i form af infektioner eller andre komplikationer, der er mere omfattende, end hvad patienten med rimelighed må tåle. Der skal herved tages hensyn til dels skadens alvor, dels patientens sygdom og helbredstilstand i ovrigt samt til skadens sjældenhed og mulighederne i øvrigt for at tage risikoen for dens indtræden i betragtning." 14

De uunngåelige skader som er mer omfattende enn det pasienten med rimelighet må tåle finner vi i den sistnevnte gruppen. Den danske "rimelighetsregelen" anvendes for behandlingsskader som ikke kunne vært unngått ved en bedre behandling, anvendelse av feilfritt medisinsk teknisk utstyr, eller ved bruk av alternativ teknikk eller metode. Bestemmelsen anvendes ikke på skader som følge av at det ikke er blitt stilt riktig diagnose av pasientens sykdom. Betingelsen for at det kan ytes erstatning etter bestemmelsen er at skadens omfang går utover hva pasienten med rimelighet må tåle. Ved avveiningen skal det legges vekt på dels skadens alvor, dels risiko for dens inntreden. Skaden skal være relativt alvorlig og sjelden, for at den berettiger

\footnotetext{
${ }^{14}$ Dansk Lov om klage- og erstatningsadgang inden for sundhedsvæsenet, kapitel 3, § 20.
} 
pasienten erstatning. Ved denne vurderingen skal det foretas en avveining av den inntrådte skaden og alvoret av grunnsykdommen pasienten ble behandlet for, herunder omfanget av den nødvendige behandling og risikoen som er forbundet med denne. Dersom pasienten har en alvorlig sykdom, vil viktigheten av behandlingen i forhold til risikoen for skade gjøre at pasienten må være forberedt på alvorlige skadefølger. ${ }^{15}$

Gjennom de danske domstoler og Pasientskadeankenævnets praksis har det skjedd en oppmykning til kravet om skadens relative alvor. I 2008 fikk $33 \%$ medhold etter den danske rimelighetsregelen. ${ }^{16}$

\subsubsection{Rimelighetsregelen i Sverige}

I Sverige har de en "rimelighetsregel" for infeksjonsskader. Bortsett fra at regelen alene omfatter infeksjonsskader, synes den å svare til den danske rimelighetsregelen.

I Patientskadelag (1996:799) §6.

"Patientskadeersättning lämnas för personskada på patient om det föreligger övervägande sannolikhet för att skadan är orsakad av..."

“ 4. överföring av smittämne som lett till infektion i samband medundersökning, vård, behandling eller liknande åtgärd..."

"Rätt till ersättning enligt första stycket 4 är utes/uten i de fall omständigheterna är sådana att infektionen skäligen måste tålas. Hänsyn skall därvid tas till arten och svårhetsgraden av den sjukdom eller skada som åtgärden avsett, patientens hälsotillstånd i övrigt samt möjligheten att förutse infektionen."

\footnotetext{
${ }^{15}$ De nordiske pasientforsikringsordninger-ligheder og forskelle. s. 78.

${ }^{16}$ Årsberetning for Patientfortsikringen 2008; www.patientforsikringen.dk
} 


\subsection{Fremstillingen videre}

I kapittel 2 behandles pasientskadelovens anvendelsesområde stedlig og geografisk. I kapittel 3 gis en kort oversikt over de ulike ansvarsgrunnlagene i $\S 2$ første ledd, etterfulgt av en fyldigere redegjørelse i kapittel 4, 5 og 6 hvor avhandlingens hovedemne blir behandlet. I kapittel 4 drøftes de to alternative grunnlagene I § 2 tredje ledd "særlig stor eller særlig uventet". I kapittel 5 undersøkes hva som er å anse som akseptabel risiko og i kapittel 6 behandles betydningen av om det er gitt tilstrekkelig informasjon. Underveis vil det $\mathrm{i}$ noen grad bli trukket inn dansk nemndspraksis, for å se på likheter og ulikheter mellom praktiseringen av rimelighetsregelen i Danmark og Norge. Til slutt i kapittel 7 kommer det noen avsluttende betraktninger. I vedlegg A medfølger to grafiske illustrasjoner, den ene gir en fremstilling av hva som er å anse som særlig uventet og den andre av "innskytspunktet” for $§ 2$ tredje ledd siste punktum, tilstrekkelig informasjon. 


\section{Pasientskadelovens anvendelsesområde m.v.}

Pasientskadeloven kommer til anvendelse ved skader voldt i institusjon under spesialisthelsetjenesten, kommunehelsetjenesten, under ambulansetransport, eller av personer som yter helsehjelp og som har offentlig autorisasjon eller lisens eller opptrer på vegne av disse.

Primærhelsetjenesten, spesialisthelsetjenesten og tannhelsetjenesten omfattes av begrepet "helsetjeneste" jfr. pasientrettighetsloven $\S$ 1-3 første ledd, bokstav d, det vil si at private helserelaterte tjenester som alternativ behandling og som utøves utenfor helsetjenesten, ikke er vernet av loven. Unntak fra dette er der alternativ behandling utøves i helsetjenesten av autorisert helsepersonell. ${ }^{17}$ Helsehjelpen må være gitt av autorisert/godkjent helsepersonell jfr.§ 1 første ledd, bokstav c. Hvem som er å anse som autorisert helsepersonell kommer frem av helsepersonelloven kapittel 9. ${ }^{18}$

\subsection{Pasientskadebegrepet}

Etter alminnelig erstatningsrett kan alle typer skader gi rett til erstatning, forutsatt at vilkårene for erstatning er oppfylt. Det samme gjelder for pasientskadeerstatning etter pasientskadeloven. Etter pasientskadeloven er grunnvilkåret at det foreligger en pasientskade, det skilles ikke mellom fysiske og ikke-fysiske skader i pasientskadeloven. ${ }^{19}$ For at skaden skal bli ansett som en pasientskade må skaden for det første være voldt på bestemte steder eller av bestemte yrkesutøvere jfr. $§ 1$ første ledd. For det andre må skaden være voldt under utførelse av bestemte typer arbeid jfr. $\S 1$ annet ledd. ${ }^{20}$ En pasientskade kan være voldt under veiledning, undersøkelse, diagnostisering, behandling, ekspedisjon av legemidler fra apotek, pleie, vaksinasjon,

\footnotetext{
${ }^{17}$ Ot.prp.nr.103 (2005-2006) s. 56 annen spalte.

${ }^{18}$ Lov om helsepersonell av 2 juli $1999 \mathrm{nr} 64$

${ }^{19}$ Ot.prp.nr. 31 (1998-99) s. 55

${ }^{20}$ Ørnulf Rasmussen, Norsk Lovkommentar, pasientskadeloven s. 2
} 
prøvetakning, analyse av prøver, røntgen, forebygging av helseskader, medisinsk forsøksvirksomhet samt donasjon av organer, blod og vev jfr. $§ 1$ annet ledd.

\subsection{Skadested}

Selv om ansvarsgrunnlaget ikke ansees oppfylt må pasientskaden ha en tilknytning til helsetjenesten etter $\S 1$ bokstav a til c. Pasientskadeloven $\S 1$ angir tre forbindelsespunkter mellom skaden og helsetjenesten. Etter første ledd litra a må skaden være voldt $\mathrm{i}$ institusjon under spesialisthelsetjenesten ${ }^{21}$ eller kommunehelsetjenesten. ${ }^{22}$ I kommunehelsetjenesten må det avgrenses mot sosialtjenester, da aldershjem, aldersboliger og boliger for psykisk utviklingshemmede faller utenfor lovens anvendelsesområde. Skal skade i slike institusjoner dekkes innenfor loven, må skaden skyldes helsehjelpvirksomhet utført av helsepersonell eller andre som er omfattet av bokstav c, se nedenfor.

\subsection{Skade voldt av helsepersonell}

Dersom pasientskaden ikke omfattes av bokstav a eller b, vil den likevel kunne omfattes dersom skaden er voldt av helsepersonell som yter helsehjelp. Kravet er at vedkommende har autorisasjon i henhold til helsepersonelloven kapittel 9. Helsepersonelloven $\S 48$ lister opp 29 ulike yrkesprofesjoner som omfattes av autorisasjonsordningen.

\subsection{Hvem kan kreve erstatning?}

Både pasienten selv og andre kan kreve erstatning etter denne loven jfr. $\S 2$ første ledd. Skader på tredjeperson dekkes av pasientskadeloven, men det må være

\footnotetext{
${ }^{21}$ Lov om spesialisthelsetjenesten av 2. juli 1999 nr. 61

${ }^{22}$ Lov om helsetjenesten i kommunen 19. november 1982 nr. 66
} 
tilstrekklig nær årsakssammenheng mellom pasientskaden og vedkommendes økonomiske tap.

\subsection{Ansvarssubjektet}

Dette reguleres av pasientskadeloven $\S 6$. Ansvarssubjektet er Norsk pasientskadeerstatning (NPE). Skadelidte skal etter loven rette erstatningskravet mot NPE og ikke direkte mot skadevolder. Finansieringen av pasientskadeerstatningen skjer ved at offentlig og privat helsetjeneste betaler tilskudd til NPE, dette er regulert i $\S 7$ for offentlig sektor og $\S 8$ for den som yter helsetjeneste utenfor den offentlige helsetjenesten. 


\section{Ansvarsgrunnlagene}

\subsection{Innledning}

Lovens bestemmelser om ansvar inneholder en hovedregel (sviktregelen) i § 2 første ledd bokstav a jf. annet ledd, enkelte særbestemmelser om objektivt ansvar i § 2 første ledd bokstavene b, c og d, og en unntaksregel i $§ 2$ tredje ledd (rimelighetsregelen). Jeg vil kort si noe om de øvrige ansvarsgrunnlagene før jeg går over til drøftelsen om $\S 2$ tredje ledd i kapittel 4

\subsubsection{Sviktregelen}

I $~ 2$ første ledd bokstav a finner vi det viktigste ansvarsgrunnlaget "svikt ved ytelsen av helsehjelp, selv om ingen kan lastes". Begrepet svikt knyttes til den skadeutløste adferd, men denne handlemåten trenger ikke være kritikkverdig. ${ }^{23}$ Når det skal vurderes om det foreligger svikt er det ikke nødvendig å utpeke en bestemt skadevolder. Det er således uten interesse for avgjørelsen i saken om det foreligger en systemsvikt eller svikt hos et enkeltindivid. For at man kan konstatere svikt må noe ha skjedd som ikke burde ha skjedd, det må ligge utenfor den faglige normen. Selv om for eksempel en lege har handlet riktig ut fra situasjonen slik legen oppfattet den vil den sammenlignes med det som er vanlig god praksis i vedkommende yrkesgruppe. Sviktbegrepet fanger opp de anonyme og kumulative feil, og kan oppstå ved en sum av mindre hendelser, på forskjellige plasser, for eksempel på forskjellige avdelinger på et sykehus eller ved forskjellige sykehus. ${ }^{24}$ Regelen må ses i perspektiv av bestemmelsen i annet ledd der det skal tas hensyn til de krav skadelidte med rimelighet kan stille til virksomheten. Skadelidtes forventninger vil måtte variere etter omstendighetene sett i lys av annet ledd. Behandles man av sivilforsvaret på et

\footnotetext{
23 Ørnulf Rasmussen. Norsk Lovkommentar, Pasientskadeloven. s.6.

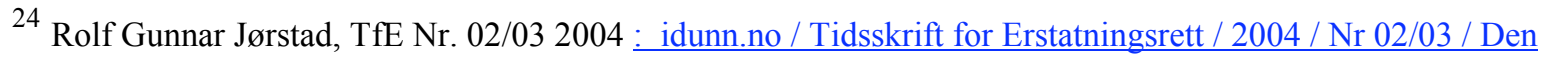
nye pasientskadeloven, særlig om offentlige helsetjenester
} 
feltsykehus etter en større ulykke, skal det mer til for å utløse ansvar enn om man behandles på et sykehus ${ }^{25}$. Ressurssituasjonen skal etter annet ledd telle med når ansvarsgrunnlaget vurderes. Selv om skadelidte måtte ha hatt en i og for seg berettiget forventninger om bedre behandling, må denne justeres etter den foreliggende ressurssituasjonen. ${ }^{26}$

\subsubsection{Reglene om objektivt ansvar}

I $\S 2$ første ledd bokstav b, gjelder det et objektiv ansvar for teknisk svikt ved apparat, redskap eller annet medisinsk utstyr som er brukt. Ved skade som oppstår ved bruk av slikt utstyr vil det være tilstrekkelig at kravet om årsakssammenheng er oppfylt. Pasienter må ha en berettiget forventning om at utstyrssvikt ikke skal opptre.

I $\S 2$ første ledd bokstav c, foreligger det et rent objektivt ansvar når skaden skyldes smitte og infeksjon, når dette ikke $\mathrm{i}$ hovedsak skyldes pasientens tilstand eller sykdom. Eksempel kan være smitte ved blodoverføring. Nedsatt immunitet medfører en egenrisiko, det gjelder ikke hvis nedsettelsen skyldes svikt ved helsehjelpen, eller helsehjelpen unnlater å forholde seg adekvat til pasientens nedsatte immunforsvar. ${ }^{27}$

I $\S 2$ første ledd bokstav d gjelder et objektivt ansvar for skade som skyldes vaksinasjon. For så vidt gjelder anbefalt eller påbudte vaksinasjoner etter smittevernloven (vaksinasjoner innenfor det såkalte vaksinasjonsprogrammet) gjelder endog en omvendt bevisbyrderegel, i det NPE må godtgjøre at en eller flere andre årsaker er mer sannsynlige enn vaksinasjonen, jf. § 3 annet ledd.

\footnotetext{
${ }^{25}$ Ot.prp.nr. 31 (1998-99) s. 90-91

${ }^{26}$ Ot.prp.nr 31 (1998-99) s.91 første spalte.

${ }^{27}$ Ørnulf Rasmussen. Norsk Lovkommentar, Pasientskadeloven. s.7.
} 


\section{Rimelighetsregelen i pasientskadeloven ( $\$ 2$ tredje ledd)}

\subsection{Innledning}

Rimelighetsregelen er et unntak fra hovedregelen om at det må foreligge en svikt helsehjelpen jfr. $\S 2$ første ledd bokstav a. Gjennom forarbeider til loven samt praksis fra domstolene og nemnda, er det gjort klart at dette er en sikkerhetsventil som bare kommer til anvendelse i særlige tilfeller. ${ }^{28}$ Dette kommer klart frem av lovens ordlyd at det kun "unntaksvis" kan ytes erstatning etter tredje ledd. Det er en høy terskel for å tilkjenne erstatning etter denne bestemmelsen.

Bestemmelsen i $\S 2$ tredje ledd lyder:

"Selv om det ikke foreligger grunnlag for erstatningsansvar etter forste og annet ledd, kan det unntaksvis ytes erstatning når det har skjedd en pasientskade som er særlig stor eller særlig uventet, og som ikke kan anses som utslag av en risiko som pasienten må akseptere. Det skal legges vekt på om det er gitt tilstrekkelig informasjon."

Regelen kommer til anvendelse for skade som er særlig stor eller særlig uventet, og hvor pasientskaden ikke kan anses som et utslag av en risiko som pasienten må akseptere. Ved vurderingen av om skaderesultatet må anses å utgjøre en risiko som pasienten må akseptere blir indikasjonen for behandling, risikoen ved ikke å behandle, hyppigheten for komplikasjoner og skadens omfang vurdert. Ved bedømmelsen av skadens omfang har det blant annet blitt lagt vekt på medisinsk invaliditet. I den endelige helhetsvurderingen legges det vekt på om pasienten er gitt tilstrekkelig informasjon.

\footnotetext{
28 Ot.prp.nr.31 (1998-99) s.91, første spalte.
} 
Det er begrenset med autoritativ rettspraksis fra den nye pasientskadeloven. Det vil derfor være nødvendig å anvende rettspraksis fra den midlertidige ordningen med pasientskadeerstatning. $\S 3$ a i de midlertidige reglene svarer til pasientskadelovens $\S$ 2 tredje ledd jfr. Rt. 2008 s. 218.

I premiss 60 uttalte Høyesterett:

"Den nye loven om erstatning for pasientskader har en annen oppbygging enn den midlertidige ordningen, men det synes å fremgå av forarbeidene at de grunnleggende trekk ved den midlertidige ordning er beholdt. Lovens $\$ 2$ tredje ledd inneholder bestemme/sen som svarer til reglenes $\S 3$ a, men fanger også opp noen tilfeller hvor det tidligere ble gitt erstatning på billighetsgrunnlag, jf. Ot.prp.nr.31 (1998-1999) side 67-69 og side 91".

I 2009 fikk 26 pasienter av 955 medhold etter unntaksbestemmelsen i § 2 tredje ledd. Dette utgjør cirka tre prosent av alle sakene. Pasientskadenemnda omgjorde seks saker til gunst for klager etter rimelighetsregelen i 2009. Disse tallene har holdt seg stabile de siste syv årene. ${ }^{29}$

\subsection{Hensynene bak rimelighetsregelen i pasientskadeloven}

Hensynene bak erstatningsretten er først og fremst prevensjon og reparasjon ${ }^{30}$. Når det gjelder hensynene bak rimelighetsregelen kommer det frem av forarbeidene at formålet er å fange opp de tilfeller hvor det ikke er grunnlag for å tilkjenne erstatning, men hvor det vil virke støtende på rettsfølelsen ikke å yte erstatning likevel. Som nevnt innledningsvis ble det i visse tilfeller der man ikke vant frem for domstolen tidligere gitt billighetserstatning (nå rettferdsvederlag). Denne ordningen ga ikke tilstrekkelig trygghet for pasienten, da pasienten etter denne ordningen ikke alltid fikk dekket sitt økonomiske tap som følge av skaden. ${ }^{31}$

\footnotetext{
${ }^{29}$ http://www.npe.no/domino/npe/cms3603no.nsf/frames/index.html?open\&4=http://www.npe.no/ lomino/npe

/cms3603no.nsf/pages/Publikasjoner_y_z.html

${ }^{30}$ Ot.prp. nr. 31(1998-99) s. 14 annen spalte.

${ }^{31}$ Ot.prp.nr 31 (1998-99) s. 68, første spalte
} 


\subsection{Var rimelighetsregelen en nyskapning?}

Forarbeidene er ikke helt entydige på om det eksisterte en rimelighetsregel i den midlertidige ordningen. I Ot. prp. nr. 31 på side 67 står at det ikke fantes noen rimelighetsregel, men på side 68 fremmer departementet forslag om å videreføre Pasientskadenemndas praksis slik rimelighetsregelen ble praktisert etter den midlertidige ordningen. Selv om det ikke kommer frem av ordlyden i den midlertidige ordningen har regelens $\S 3$ a blitt praktisert som en sikkerhetsventil. I Arbeidsgruppens notat antyder man ved gjennomgangen av pasientskadeordningen at man hadde tenkt på en rimelighetsregel og at den allerede var under utvikling:

"... er den mulige skaden av storre omfang, vil grensen for hva som anses som akseptabel risiko snevres tilsvarende inn. Alvorlige skader vil derfor oftere kunne fore til erstatning på grunn av uakseptabel risiko." 32

Praksis fra Pasientskadenemnda viser at det har vært praktisert en rimelighetsregel under de midlertidige reglene. Dette er også stadfestet gjennom Høyesterettspraksis jfr. Rt. 1998 s.1336, Rt. 1998 s. 1538, Rt 2006 s. 1217 og Rt. 2008 s. 218.

Etter de midlertidige reglene fremgikk erstatningsgrunnlaget av $\S 2$ og $\S 3$ lest $\mathrm{i}$ sammenheng. I de midlertidige reglene var ansvarsgrunnlaget i $\S 2$, med mindre tilfellet falt inn under begrensningen $i$ ansvaret $i \S 3$. Dette innebar at dersom det var gitt adekvat behandling, hadde ikke pasienten rett på erstatning jfr. $\S 3 \mathrm{~d}$. Men det innebar videre at det likevel kunne ytes erstatning dersom skaden var en følge av en risiko som ikke må aksepteres jfr. $\S 3$ a. Dette tilsvarer pasientskadeloven $\S 2$ tredje ledd, jfr. Rt. 2008 s. 218.

I Arbeidsgruppens notat understrekes det at skadens omfang og sjansen for at den skal inntreffe må sees i sammenheng med sykdommens art. I noen tilfelle må pasienten akseptere en alvorlig skade som ikke er til å unngå ved undersøkelse eller helbred. Ved sjeldne, men alvorlige skader, som står i sterkt misforhold til størrelsen

\footnotetext{
${ }^{32}$ Arbeidsgruppens notat om erstatningsordningen for pasientskader, 1987, s. 24.
} 
på inngrepet og sykdommens art, kan man ikke si at det foreligger en risiko som må aksepteres ut fra den medisinske kunnskap på skadetidspunktet. ${ }^{33}$

\subsection{Utgangspunktet ved erstatning etter $\S 2$ tredje ledd}

Utgangspunktet for anvendelse av tredje ledd er at det ikke foreligger svikt ved ytelsen av helsehjelpen. Dersom skaden er voldt ved svikt vil hovedregelen i § 2 første ledd bokstav a komme til anvendelse.

\subsection{Tilfeller som ikke omfattes av regelen}

Det er lang nemndspraksis for at unntaksregelen i § 2 tredje ledd ikke kommer til anvendelse ved rene diagnoseskader. Dersom diagnostiseringen har vært i tråd med vanlig god praksis og innenfor de ressurser og muligheter helsevesenet hadde på det aktuelle tidspunkt, vil skade som følge av forsinket eller uriktig diagnose ikke falle innenfor anvendelsesområdet til $\S 2$ tredje ledd. ${ }^{34}$ Unntaksbestemmelsen kan imidlertid anvendes ved skade som følge av aktive tiltak som for eksempel ryggmargsprøver og bronkoskopiundersøkelser, hvor helsehjelpen er i samsvar med kravene til god faglig standard, men der det likevel inntrer skade. ${ }^{35}$

\subsection{Vilkårene i § 2 tredje ledd}

For at $\S 2$ tredje ledd skal komme til anvendelse må visse vilkår være oppfylt, det må foreligge en pasientskade, pasientskaden må være særlig stor eller særlig uventet slik at den ikke kan sies å være en risiko som pasienten må akseptere. I vurderingen skal legges vekt på om det er gitt tilstrekkelig informasjon på forhånd.

\footnotetext{
33 op.cit.

${ }^{34}$ TfE Nr. 1-2/2006/årgang 3 s. 110-111 av Jan Storvik

${ }^{35}$ Jan Storvik, forelesning ved NPE 22.3.10
} 
Hva som er å anse som særlig stor og særlig uventet må vurderes opp mot sykdommens alvor. Dette gjøres ved å sette forholdet mellom sykdommen og skaden opp mot hverandre. I begge tilfellene blir det sentrale å trekke grensen mot en akseptabel risiko. I begge tilfeller skal det legges vekt på om det er gitt tilstrekklig informasjon. Her vil det være nødvendig å trekke en grense mellom tilstrekkelig informasjon og informasjonsplikten. Dersom det foreligger brudd på informasjonsplikten $^{36}$ vil det foreligge en svikt ved helsehjelpen og spørsmålet skal da løses under sviktreglen i $\S 2$ første ledd bokstav a.

\subsection{Særlig stor pasientskade}

\subsubsection{Innledning}

Etter ordlyden i pasientskadeloven $\S 2$ tredje ledd, første alternativ stilles det et kvalifisert krav til at pasientskaden må være særlig stor. Hva som er å anse som særlig stor sies det ikke noe om verken i lovteksten eller i forarbeidene. Lødruputvalget finner det riktig å la de sjeldne, men alvorlige skader falle innenfor pasientskadeordningen. ${ }^{37}$ I Ot.prp. nr 31 brukes ikke uttrykket "særlig stor skade", men "sjeldne og alvorlige komplikasjoner". 38 En naturlig forståelse av ordet ”alvorlig" er at skaden må være betydningsfull, farlig eller livstruende. En særlig stor skade kan referere til at skaden må ha et stort omfang hvor dette sammenlignes med forholdene slik det var før skaden oppstod: er differansen stor, vil skadens omfang kunne sies å være betydningsfull. Selv om det ikke kommer til uttrykk i lovteksten stilles det et krav til skadens alvorlighet for at man skal kunne anse den som særlig stor jfr. NOU: 1992: 6 s. 77-78 der utvalget finner det riktig å la de sjeldne, men alvorlige skader falle innenfor.

\footnotetext{
${ }^{36}$ Pasientrettighetsloven $\S 3-2(1)$.

${ }^{37}$ NOU 1992:6 s. 77-78

${ }^{38}$ Ot.prp.nr 31 (1998-99) s. 91, første spalte
} 


\subsubsection{Skadens omfang i forhold til grunnlidelsen}

Det kommer frem av arbeidsgruppens notat at skadens omfang og sjansen for at den skal inntreffe må sees i sammenheng med sykdommens art. I noen tilfeller må man for eksempel ved å redde pasientens liv og helbred akseptere en alvorlig skade som ikke er til å unngå ved den undersøkelsen eller behandlingen som foretas. I arbeidsgruppens notat drøfter de "skadens omfang" som er synonymt med skadens størrelse og alvorlighetsgraden av skaden. ${ }^{39}$ I begge tilfeller blir dette en grensedragning for hva som er en akseptabel risiko.

Dersom grunnlidelsen er alvorlig slik at livsnødvendig behandling var tvingende for å redde pasientens liv vil pasienten også måtte tåle et større skadeomfang og akseptere en større risiko for skade enn dersom grunnlidelsen er mindre alvorlig. Ved vurderingen av grunnlidelsens art må man se på utgangspunktet for behandlingen.

I en sak fra Pasientskadenemnda (PSN 2005-619) kommer betydningen av grunntilstanden ved en ikke livsnødvendig behandling frem. Saken gjaldt en pasient som etter operasjon for trange forhold i nakken fikk en påvirkning av ryggmargen som førte til nummenhet $\mathrm{i}$ høyre ben. Årsaken til skaden var sannsynligvis at ryggmargen hadde fått en lettere dult under operasjonen, idet det var uttalt trangt $\mathrm{i}$ ryggmargen. Risikoen for et nevrologisk utfall av denne typen oppstår i cirka 0,3\% av tilfellene. Pasientskadenemnda la til grunn at det var god indikasjon for operasjon og pasientens grunntilstand med uttalt trange forhold gjorde at skaden ble ansett å være utslag av en risiko ved behandlingen som må anses akseptabel.

Et eksempel der Høyesterett ser på grunnlidelsens alvor er Sarkomdommen. ${ }^{40}$ Høyesterett kom til at det ikke forelå svikt ved behandlingen. Her vurderte retten skadens omfang i forhold til grunnlidelsen. Saken ble vurdert etter

\footnotetext{
${ }^{39}$ Arbeidsgruppens notat om erstatningsordningen for pasientskader, 1987. s. 24

${ }^{40}$ Rt. 2008 s. 218
} 
"rimelighetsregelen" i de midlertidige reglene for pasientskadeerstatning. Pasienten fikk på grunn av en meget alvorlig kreftsykdom omfattende cellegift- og strålebehandling som medførte svært store skader.

Høyesterett kom til at selv om pasienten hadde fått uventet store og invalidiserende skader med et større og mer alvorlig omfang enn hva man anser som ventet og påregnelig, ligger de innenfor det pasienten må akseptere. Når sykdommens alvor var livstruende må man akseptere en høy risiko for alvorlige komplikasjoner.

Dersom grunnlidelsen er alvorlig vil som oftest kravet til særlig stor skade ikke bli tilfredsstilt. Ved vurderingen av skadens relative alvor foretas det en avveining av alvoret av den inntrådte skaden på den ene siden, og på den andre siden alvoret av den sykdommen pasienten ble behandlet for, herunder omfanget av den nødvendige behandlingen og den risiko som er forbundet med denne. Jo mer alvorlig pasientens sykdom er, og jo mer omfattende behandlingen er, desto større behandlingsskader vil pasienten måtte tåle uten erstatning. Det er sikker praksis fra nemnda og Høyesterett at man i de tilfeller det settes inn livsnødvendig behandling også må akseptere alvorlige skader.

\subsubsection{Dansk praksis på skadens omfang i forhold til grunnlidelse}

Den danske rimelighetsregelen ser ikke ut til å bli praktisert like strengt som den norske regelen ved alvorlig grunnsykdom. Fra dansk praksis har vi en sak der en kvinne på 55 år fikk konstatert en svulst i venstre hjernehalvdel, og man foretok en biopsi for nærmere utredning. Forut for operasjonen hadde man informert pasienten om den risiko som var forbundet med inngrepet. Inngrepet forløp umiddelbart uten komplikasjoner. Pasienten våknet ikke opp etter operasjonen og en CT-scanning viste en voldsom blodansamling i pannelappen. Man foretok en akutt operasjon med tømming av blodansamlingen. Pasienten våknet fortsatt ikke ordentlig opp og etter en ny CT-scanning fant man en blodansamling ved den harde hjernehinnen, kvinnen ble 
operert igjen med tømming av blodansamlingen. Da pasienten våknet opp, konstaterte man at hun hadde utviklet en høyresidig lammelse.

Patientforsikringen vurderte ved sin avgjørelse at det var tale om en kjent, men ytterst sjelden komplikasjon ved biopsi av hjernesvulst. Den mente skaden var tilstrekkelig alvorlig til å oppfylle betingelsene i loven, selv om kvinnen hadde en alvorlig grunnsykdom. Den mente også at svulsten med tiden i seg selv ville ha medført alvorlige følger med høyresidig lammelse, med talevansker, som var de samme symptomene som pasienten hadde utviklet på grunn av blodansamlingen, men at det ville gått flere år før dette ville realisert seg. ${ }^{41}$ Pasienten fikk medhold i sitt erstatningskrav.

\subsubsection{Skadens omfang i forhold til indikasjon for inngrepet}

Ved vurderingen av om en skade er å anse som særlig stor sees skadeomfanget også i sammenheng med indikasjon for inngrepet. Ved vurderingen av indikasjon for behandlingen inngår nytten av behandlingen på det aktuelle tidspunkt opp mot nytten av å gi behandling på et senere tidspunkt. Dersom en senere behandling øker risikoen for skader og reduserer sjansen for bedring, vil det være solid indikasjon for behandling, i motsatt tilfelle vil det være relativ indikasjon.

Et eksempel fra Pasientskadenemnda der nemnda vurderer nødvendigheten av behandlingen opp mot risikoen for skade ved å vente med operasjonen, finner vi i PSN 2006-89. I denne saken krevde pasienten erstatning for skader $\mathrm{i}$ form av lammelser i tale-, arm- og beinfunksjon som følge av hjerneinfarkt i forbindelse med operativ behandling for forsnevring på halspulsåren. Pasienten hadde tidligere hatt flere episoder med TIA, lammelser i armene og synsforstyrrelser. Ved vurderingen av pasientskadelovens $\S 2$ tredje ledd viser nemnda til nødvendigheten av inngrepet, og

\footnotetext{
${ }^{41}$ Afgørelser og praksis gennem 10 år, s. 105-106.
} 
uttaler at risikoen for hjerneinfarkt var større ved ikke å operere. Det forelå derfor god indikasjon for operasjonen. Nemnda legger også vekt på at pasienten før inngrepet hadde hatt en rekke nevrologiske utfall. Risikoen for skade var kjent, noe pasienten også hadde blitt informert om. Sett hen til skadens omfang og grunnlidelsens alvorlighet kom nemnda til at bestemmelsen i $\S 2$ tredje ledd ikke kom til anvendelse. To avgjørelser fra Pasientskadenemnda illustrerer betydningen av indikasjonen ved vurderingen av om skaden ligger innenfor hva som må aksepteres. Begge sakene omhandler en nerveskade etter en ryggoperasjon.

I den første saken (PSN 2007-768) fikk pasienten medhold. I denne saken krevde en kvinne på 75 år erstatning for skade som oppstod etter operasjon på grunn av betydelig spinal stenose. Pasienten hadde syv måneder tidligere fjernet et tidligere innsatt avstivningsmetall, noe som dempet ryggsmertene. Etter MR bilder tatt et par måneder senere ble det funnet betydelig spinal stenose, hun ble derfor operert fem måneder senere. Etter operasjon tilkom økende lammelser og det ble påvist et hematom som klemte mot nerverøttene. Kvinnen måtte gjennom to operasjoner for fjerning av hematomet.

Pasientskaden bestod av behandlingsrelaterte pareser i begge beina, sensibilitetstap og blære-rektumparese, hun ble også for det meste avhengig av rullestol, nemnda uttalte:

"Hva gjelder indikasjon for operasjonen [...] anser nemnda at den har vert relativ[...] Det er for ovrig ytterst sjelden at det oppstår så omfattende skader i tilknytning til denne typen inngrep. Samlet sett finner nemnda at risikoen for komplikasjoner er av et så stort omfang [min uthevning], at det ligger utenfor hva pasienten må akseptere."

I denne saken forelå det en relativ indikasjon, det vil si at behandlingen ikke var livsviktig eller tvingende nødvendig. Det kommer frem at kvinnen hadde hatt god effekt av operasjonen som ble utført i mars 2006. Da det ble oppdaget betydelig spinal stenose etter MR bildene som ble tatt i mai 2006, står det ikke noe om at 
kvinnen i denne perioden hadde økte ryggsmerter som gjorde ny operasjon nødvendig. Det var denne siste operasjonen som førte til dannelse av et hematom og førte til lammelser.

I den andre saken (PSN 2004-546) hadde en kvinne på 76 år i flere år hatt ryggplager med betydelig forverring den siste tiden. Det var av den grunn en god indikasjon for operasjon. Det oppstod en rift i den ytre hinnen rundt ryggmargen under inngrepet, med påfølgende nerveskade. Pasienten fikk etter inngrepet betydelige plager med inkontinens for urin og avføring. Pasientskadenemnda uttrykte følgende:

"I nærværende sak var indikasjonen for det operative inngrepet solid, da det forelå betydelige symptomer i venstre ben forut for inngrepet. Ubehandlet ville symptomene over tid oke på og gi ytterligere smerter, tap av funksjon/føletap i benet. Sett hen til dette legger nemnda til grunn at risikoen for skade ligger innenfor det som må aksepteres."

Av momenter som ble vurdert i begge sakene var indikasjonen for operasjon, skadeomfang, grunnlidelse og risiko. I den første saken var det en relativ indikasjon for operasjon, skadeomfanget var omfattende, grunnlidelsen ga seg ikke utslag $\mathrm{i}$ betydelige ryggsmerter, risikoen for denne type inngrep var 0,05\%-0,2\%. Skadens omfang ble i forhold til inngrepets størrelse ansett som særlig stor. I den andre saken var det "solid indikasjon", skadeomfanget var ikke så omfattende som i den første saken, grunnlidelsen ga utslag i betydelige smerter, hvorav operasjonen ble fremskyndet på grunn av betydelig forverring den siste tiden, risikoen var ikke særlig uventet, da den ble anslått til å ligge mellom 10 og $20 \%$.

Ut fra dette ser vi at indikasjonsmomentet er et viktig og avgjørende moment. Dersom det er solid indikasjon og tilstanden ville forverret seg uten behandling må pasienten tåle større behandlingsskader og akseptere en større risiko enn om det var en mer uklar indikasjon, der man kunne ventet eller latt være å gjennomføre operasjon. 


\subsubsection{Dansk praksis på skadens omfang}

En 37 år gammel kvinne ble operert for skiveprolaps i nakken, man satte inn en knokkelpropp. Under inngrepet gled den anvendte tangen og det oppstod dermed en påvirkning av ryggmargen. Pasientskaden gav seg utslag i kraftige smerter i høyre arm og hånd, med mulige lammelser av bicepsmuskelen med nedsatt kraft og følesans $\mathrm{i}$ hånd og fingre.

Patientforsikringen vurderte saken og kom til at det forhold at tangen gled var et hendelig uhell der ingen kan klandres, behandlingen avvek ikke fra optimal standard. De fant allikevel at skadens følger sett i forhold til pasientens grunnsykdom var tilstrekkelig alvorlig og sjelden, og hun fikk dermed medhold etter den danske rimelighetsregelen. ${ }^{42}$

Denne saken har mange likhetstrekk med de ovennevnte sakene behandlet i Pasientskadenemnda. Vi ser at grensen for hva som er å anse som en stor skade selv om det er god indikasjon for operasjon er lavere i dansk rett enn etter norsk rett. I Norge praktiseres regelen etter en streng linje.

\subsubsection{Skade oppstått ved forebyggende behandling}

I saken som er nevnt i punkt 4.7.2 hadde pasienten en livstruende kreftsykdom og det var nødvendig å sette inn en omfattende behandling for å redde guttens liv. Noen ganger kan det være nødvendig å gi behandling av forebyggende karakter for å hindre skade/sykdom selv om pasienten ikke har plager av sin tilstand. Spørsmålet blir da hvordan man skal vurdere sykdommens art opp mot skadens omfang. Vil det stilles et lavere krav til særlig stor skade dersom det er et resultat av forebyggende behandling? Fra nemndspraksis har vi en avgjørelse som behandler dette spørsmålet.

\footnotetext{
42 Patientforsikringen, Afgørelser og praksis gennem 10 år, 2002. s. 109.
} 
Det ble under en utredning for rykninger i den ene delen av ansiktet oppdaget en aneurisme (lokal utposning av blodåre) i fremre hjernehalvdel. Det ble anbefalt innsetting av metalltråd (coiling) av aneurismen. Under coilingen ble det registrert lekkasje/blødning fra aneurismen. Pasienten måtte på grunn av dette gjennom flere reoperasjoner. Etter endt behandling klarte hun kun å bevege venstre hånd, mistet svelgefunksjonen og kunne ikke kommunisere verbalt eller med kroppsspråk. Kvinnen gikk fra å være $100 \%$ arbeidsfør til å bli $100 \%$ ufør. ${ }^{43}$

Ved vurderingen av om $\S 2$ tredje ledd kom til anvendelse så nemnda på pasientens grunnsykdom opp mot skaden som hadde realisert seg. I sin vurdering la de vekt på at kvinnen ikke hadde hatt plager av aneurismen, operasjonen var av forebyggende karakter, faren for ruptur var ukjent, det var en relativ indikasjon for operasjon og risikoen for komplikasjoner ved operasjonen var under $0,5 \%$. Kvinnen som før skaden var $100 \%$ arbeidsfør ble etter operasjon 100\% ufør. Nemnda kom til at kvinnen hadde fått en "særlig stor" skade som ikke kan anses som utslag av en risiko pasienten må akseptere. Kvinnen fikk medhold etter unntaksbestemmelsen i tredje ledd.

Utdrag fra PSN-2007-15:

"Sett hen til at pasienten ikke hadde plager fra aneurismet for operasjonen, at operasjonen var av forebyggende karakter for en rupturfare hvis storrelse ikke sikkert er kjent, at det på bakgrunn av det aktuelle aneurismet forelå relativ indikasjon for operasjon, at risikoen for komplikasjon ved coiling er under 0,5\%, at det fremstår som noe usikkert hva pasienten på forhånd ble informert om, sammenholdt med den store pasientskaden som foreligger, er nemnda av den oppfatning at skaden ikke kan anses som et utslag av en risiko som må anses akseptabel..."

${ }^{43}$ PSN-2007-15 
Også denne avgjørelsen er et eksempel på at indikasjonsstillingen kommer inn som et viktig moment $\mathrm{i}$ vurderingen ved forebyggende behandling. Når behandlingen er av forebyggende art, pasienten ikke har nevneverdige plager av sin grunntilstand og det derfor foreligger en relativ indikasjon for behandling, taler dette for at pasienten ikke skal måtte akseptere omfattende behandlingsskader.

\subsubsection{Graden av medisinsk invaliditet}

Den medisinske invaliditetsgrad vil ofte gi en god veiledning om følgene av en pasientskade og gir i noen grad en objektiv veiledning på hvor stor skaden er. Det kommer ikke frem av pasientskadeloven eller forarbeidene at den medisinske invaliditetsgraden skal benyttes som et mål for hvor stor skaden er, men man kan likevel se at Pasientskadenemnda og Høyesterett har benyttet denne som et moment for å si noe om skadeomfanget. Spørsmålet er om det finnes en prosentgrense på medisinsk invaliditet som erkjennes som særlig stor skade.

I et eksempel fra Pasientskadenemnda (PSN 2007-768), som også er omtalt under punkt 4.7 .7 ble den medisinske invaliditeten satt til $80 \%$. Her sammenlignet Pasientskadenemnda den medisinske invaliditeten med skadeomfanget i Cauda equina-dommen (Rt. 1998 s. 1538), der den medisinske invaliditeten ble satt til 32,5\%. Pasienten i Cauda equinadommen fikk ikke erstatning da Høyesterett kom til at skaden i det tilfellet ble ansett for å ligge innenfor en akseptabel risiko fordi den ikke sto i sterkt misforhold til størrelsen på inngrepet og sykdommens art Nemnda uttaler i sak PSN 2007-768:

"/ nærværende tilfelle foreligger det en betydelig varig medisinsk invaliditet på minst 80 \% [...] Skaden består i behandlingsrelaterte pareser i begge bein, sensibilitetstap og blærerektumparese. Hun er for det meste avhengig av rullestol[...] Det er for ovrig ytterst sjelden at det oppstår så omfattende skader i tilknytning til denne typen inngrep...”. 
Skadeomfanget kvalifiserte som en særlig stor skade og nemnda tilkjente erstatning på det grunnlaget. ${ }^{44}$

Den såkalte Angiografidommen (Rt.2006 s. 1217) underbygger antagelsen om at en pasientskade som gir rundt 30\% medisinsk invaliditet ikke er å anse som en særlig stor skade. Den medisinske invaliditeten ble i foreliggende tilfelle satt til $30 \%$, mens den ervervsmessig uføregraden ble satt til 100\%. Det var solid indikasjon for å foreta en angiografiundersøkelse og den senere hjerteoperasjonen, og risikoen for aortasplitting ved angiografiundersøkelsen ble oppgitt å være på under 0,1\%. Det var videre en ikke ubetydelig skaderisiko forbundet med hjertebehandlingen. Nerveskaden i armen oppstod som en indirekte følge av disseksjonen. Høyesterett kom til at selv om skaden gir betydelige plager er ikke skadeomfanget så stort at det kunne danne grunnlag for erstatning, når skaden ble sammenholdt med den livsnødvendige behandlingen pasienten fikk (solid indikasjon). Ved vurderingen av skadens omfang, har det også vært lagt en viss vekt på skadens økonomiske omfang. ${ }^{45}$ Men selv om denne pasienten ikke lengre kunne stå i sitt arbeid og den medisinske invaliditeten var satt til 30\%, var ikke skadens omfang så stort at det $ø$ konomiske tapet fikk noen avgjørende selvstendig betydning for resultatet.

Av de avgjørelsene som er trukket frem er det ikke grunnlag for å konkludere med at det finnes noen klar prosentgrense for når en viss medisinske invaliditet er å betrakte som en særlig stor skade. Det avgjørende synes å bli at den medisinske invaliditeten blir et viktig moment $i$ helhetsvurderingen av skadens omfang sammenlignet med grunnlidelsens alvor.

\footnotetext{
${ }^{44}$ PSN 2007-768

${ }^{45}$ Norsk Lovnøkkel, Per Kåre Herredsvela. Pasientskadeerstatning s. 17.
} 


\subsubsection{Særlig stor skade i forhold til inngrepets størrelse}

Ved en behandling/operasjon som er klassifisert som nokså uproblematisk, vil skadens omfang vurderes opp mot inngrepets størrelse og kompleksitet. Fra Pasientskadenemnda finnes en avgjørelse hvor man har foretatt en slik vurdering. ${ }^{46}$ Pasientskadenemnda ga pasienten medhold etter pasientskadeloven $\S 2$ tredje ledd da skaden ble ansett som særlig stor ut fra inngrepets størrelse. Avgjørelsen illustrerer betydningen av inngrepets størrelse i forhold til skadens omfang.

Pasienten hadde i 2001 pådratt seg et knusningsbrudd i høyre legg, bruddet tilhelte med feilstilling og forkorting. På grunn av plager ble det satt på en ramme som gradvis forlenget skinnbenet. Pasienten fikk strekkskader på nerven med påfølgende komplekst regionalt smertesyndrom av type to. Det var god indikasjon for kirurgisk korrigering i dette tilfellet, og risikoen for en slik intens og kompleks smertetilstand skal inntreffe er på under en prosent. Den medisinske invaliditeten var anslått til 60\% Pasientskadenemnda kom til at pasientens tilstand ikke var å anse som utslag av en akseptabel risiko. Avgjørelsen inneholder ingen dyp drøftelse av de ulike momentene, men skadeomfanget sett opp mot grunnlidelsens art og det forhold at inngrepet var å anse som enkelt kan synes avgjørende for at resultatet ikke var å anse som en risiko som pasienten måtte akseptere. Skadens omfang kan i dette tilfellet sies å stå i sterkt misforhold til størrelsen på inngrepet og grunnskadens art.

En annen sak hvor skadens omfang ble ansett for å ligge utenfor det pasienten må akseptere finner vi i PSN 2006-463. Saken gjaldt en pasient som under en endetarmsundersøkelse for hemoroider fikk en tarmperforasjon hvoretter det ble behov for to operasjoner samt utlagt tarm i seks måneder. Det var god indikasjon for undersøkelsen og risikoen for tarmperforasjon var under $0,03 \%$. Pasienten hadde hatt langvarige komplikasjoner etter noe som i utgangspunktet skulle være en enkel undersøkelse, og etter nemndas syn fremsto skaden som særlig stor og særlig uventet. Etter en helhetsvurdering kom

\footnotetext{
${ }^{46}$ Saksnr. N2007/0920
} 
Pasientskadenemnda til at komplikasjonen oversteg den risiko som må aksepteres, og pasienten fikk medhold etter $\S 2$ tredje ledd.

\subsection{Oppsummering av hva som er å anse som særlig stor skade}

Hvilken vekt har grunnlidelsen, indikasjon, medisinsk invaliditet og inngrepets størrelse ved vurderingen av om skaden er særlig stor? Selv om skadens omfang isolert sett er stor, vil omfanget av skaden være relativ, man må sammenligne skaden med pasientens utgangspunkt. Har pasienten en alvorlig grunnlidelse og det er solid indikasjon for behandling for å redde liv, vil det være med på øke kravet til skadens størrelse betraktelig. Pasientene må tåle en høy medisinsk invaliditet og store behandlingsskader uten erstatning dersom man har en alvorlig grunnlidelse. På den andre siden vil stor skade som står i sterkt misforhold til størrelsen på inngrepet og sykdommens art ligge utenfor den risiko som må aksepteres.

\subsection{Særlig uventet pasientskade}

\subsubsection{Innledning}

Når vil en skade kunne betegnes som "særlig uventet"? En naturlig forståelse av særlig uventet er at skaden er uforutsett, tilfeldig og overraskende og ligger utenfor de mer kjente komplikasjoner på skadetidspunktet.

Lødruputvalget fant det riktig å la de sjeldne, men alvorlige skader falle innenfor en pasientskadeordning hvor disse ikke har sammenheng med grunnsykdommen. Begrunnelsen for erstatning er at de uventede, alvorlige skader i et ellers enkelt sykdomsbilde vil styrke tillitsforholdet mellom pasienten og sykehuset. Ved de mer alvorlige sykdomstilfelle må det være slik at behandlingen kan medføre risiko for at det fra tid til annen inntrer komplikasjoner, uten at pasienten har krav på erstatning. 
For å avgjøre om en skade/komplikasjon er uventet ser man hen til risikoen for at den aktuelle skaden vil realisere seg. For å vurdere om pasientskaden er særlig uventet vil man også her se hen til indikasjon for behandlingen, sykdommens alvor, risiko for komplikasjoner og skadens omfang. En uventet skade som gir ubetydelig skadeomfang ligger innenfor det pasienten må akseptere og er ikke erstatningsrettslig vernet. Hvor grensen går for hva som anses som særlig uventet vil bli belyst ved bruk av nemndsavgjørelser.

\subsubsection{Særlig uventet i forhold til risikoens størrelse}

Lødruputvalget forutsatte at de skader som skulle være erstatningsbetingende, var av en slik karakter at de fremstod som en mer statistisk enn reell mulighet for den konkrete pasient, og at det var medisinsk forsvarlig å ta risikoen ut fra pasientens tilstand. $^{47}$

En sak fra Pasientskadenemnda som ble løst etter pasientskadeloven, gjaldt en pasient som hadde fått varige plager etter at det tilkom lekkasje i en tarmskjøt $i$ forbindelse med tarmoperasjon. Komplikasjonen som tilkom i det aktuelle tilfelle er en kjent, men nokså sjelden komplikasjon og oppstår i 3-5 \% av tilfellene, og kan ”...ikke anses særlig uventet $i$ lovens forstand". 48

I saken som nevnt over i punkt 4.7 .6 (PSN-2007-15) om kvinnen som under operasjonen i hjernen fikk en perforasjon av aneurismen, kom den sakkyndige til at komplikasjonen var kjent, men sjelden, risikoen for skade var angitt til 0,5\%.

"Skaden er meget sjelden, men har etter nemndas oppfatning ikke karakterisert som særlig uventet'. 49 I denne saken oppfylte dog pasienten kravet til særlig stor skade.

\footnotetext{
${ }^{47}$ NOU 1992:6 s. 77-78

${ }^{48}$ PSN 2007-856

${ }^{49}$ PSN 2007-15
} 
I en annen nemndsavgjørelse (PSN 2005-689) anførte pasientens advokat at "...skaden er så sjelden at dette må oppfattes som scerlig uventet i pasientskadelovens forstand". Saken omhandler en pasient som etter operasjon for carpal tunnel syndrom (smerter, prikking og dovenhet og til tider muskelsvinn i hånd og fingre på grunn av trykk på nervus medianus $\mathrm{i}$ håndrotsgangen) fikk komplekst regionalt smertesyndrom. Det fremkommer av den medisinske vurderingen at det var indikasjon for operasjon og at komplikasjonen var sjelden og alvorlig og inntreffer $i$ under en prosent av tilfellene. Tilstanden opptrer etter skader eller operasjoner, og rammer vilkårlig.

Pasientskadenemnda uttaler:

"Etter en konkret vurdering hvor risiko for komplikasjoner vurderes $i$ forhold til indikasjonsstillingen og komplikasjonens art og omfang[...] ikke foreligger en særlig stor eller uventet pasientskade. Etter nemndas oppfatning er skaden ikke utslag av en større risiko ved behandlingen enn det som må aksepteres".

En særlig uventet pasientskade finner vi i PSN 2007-768 (se punkt 4.7.4). Saken gjaldt kvinnen som etter en ryggoperasjon fikk pareser i begge bena, sensibilitetstap og blære-rektumparese. Komplikasjonen var kjent men sjelden og ble angitt til å ligge mellom $0,05 \%$ og $0,2 \%$. Dette ble etter nemndas synspunkt ansett som ytterst sjeldent. Det er vanskelig å si noe om dette vilkåret alene ville gitt pasienten medhold etter $\S 2$ tredje ledd ettersom vilkåret for særlig stor skade også var oppfylt.

Den overnevnte praksisen viser at selv om det er tale om en lav sannsynlighet for at risikoen inntrer, er det ikke tilstrekelig i forhold til vilkåret særlig uventet etter rimelighetsregelen. Det ser ut til at man kan trekke en grense for hva som er å anse som særlig uventet når den inntreffer ned mot $0,05-0,2 \%$. 


\subsubsection{Særlig uventet i forhold til informasjonen som ble gitt}

Når en ikke har fått informasjon om mulige risikoer ved behandlingen vil ved skadens inntreden alltid komme uventet. Spørsmålet er da om mangelen på konkret informasjon vil senke kravet til hva som er å anse som særlig uventet i relasjon til § 2 tredje ledd. Etter lovens ordlyd, skal det etter leddets siste punktum legges vekt på den informasjonen pasienten har fått i rimelighetsvurderingen. Selv om det medisinsk måtte være riktig å ta en kalkulert risiko, kan dette utløse erstatningsplikt dersom pasienten ikke er tilstrekkelig informert.

En sak fra Borgarting lagmannsrett kan illustrere innvirkningen av mangel på informasjon ved vurderingen av om skaden er særlig uventet. Saken gjaldt en 50 år gammel kvinne som ble påført en nerveskade ved en hofteoperasjon, som hun på forhånd ikke hadde blitt informert om kunne inntre. Skaden førte til nedsatt gangfunksjon i venstre ben, såkalt dropfot. Lagmannsretten fant ikke at den manglende informasjonen om risiko for nerveskade var av avgjørende betydning for vurderingen av om skaden i dette tilfellet kan anses som særlig uventet. Retten pekte blant annet på at selv om kvinnen ikke var gjort kjent med den konkrete risikoen for nerveskade, var hun generelt kjent med at det forelå en risiko for komplikasjoner ved en operasjon av det omfang det var tale om her, og hun var også gjort kjent med enkelte av de komplikasjoner som kunne oppstå. Lagmannsretten vurderte så om skaden var uventet og uttaler:

"Som fremhevet [...] er det ved innsetting av hofteproteser en viss risiko for nerveskade, anslagsvis en til to prosent. Objektivt sett kan skaden da ikke anses som uventet" ${ }^{50}$

At pasienten ikke har fått konkret informasjon om risiko vil ut fra dette ikke ha avgjørende betydning ved vurdering av om skaden er særlig uventet.

${ }^{50}$ LB $2007 / 16311$ 


\subsubsection{Særlig uventet i forhold til inngrepets størrelse}

Ved sjeldne skader som står i sterkt misforhold til størrelsen på inngrepet, blir spørsmålet om det foreligger en risiko som må aksepteres. Lødruputvalget fant det riktig å la de sjeldne, men alvorlige skader falle innenfor en pasientskadeordning hvor disse ikke har sammenheng med grunnsykdommen. At en pasient skal komme ut av en behandlingssituasjon med mer omfattende skader enn han eller hun tidligere hadde ved et ellers enkelt sykdomsbilde, vil etter utvalgets syn virke urimelig.

Fra nemnda er det en avgjørelse som gjelder smerteplager i armen etter blodprøve. ${ }^{51}$ Saken gjaldt en pensjonert kvinne på 76 år som var til rutineundersøkelse hos sin fastlege, der det ble tatt blodprøve i armen. På kvelden fikk hun bloduttredelse, hevelse og smerter i armen, hun ble senere operert som følge av plagene. Pasienten sliter i dag med å kunne utføre de hverdagslige gjøremål og aktiviteter.

Pasientskadenemnda kom til at skaden som hadde oppstått var å anse som svært uventet og at den ligger utenfor den risiko det er rimelig at pasienten må akseptere i forbindelse med en enkel prosedyre som blodprøvetakning. Det er ingen begrunnelse i avgjørelsen og momenter som grunnlidelse, indikasjon og skadens omfang er ikke drøftet. Ut fra sakens opplysninger er det vanskelig å si om kvinnen fikk medhold i sitt erstatningskrav alene fordi skaden var uventet, da det fremkommer av saksfremstillingen at skadeomfanget var av en viss størrelse i forhold til inngrepets størrelse.

\subsubsection{Oppsummering av hva som er å anse som særlig uventet pasientskade}

Bortsett fra den overnevnte sak, har pasientene i de øvrige avgjørelsene også hatt et stort skadeomfang i tillegg til at komplikasjonen var uventet. Ut fra dette kan det se ut til at det kreves et visst skadeomfang, av en ikke ubetydelig alvorlighetsgrad og at skaden i tillegg må være uventet for at rimelighetsregelen skal kommer til anvendelse. Dette finnes det støtte for i Ot.prp.nr 31 side 91, der det står at

\footnotetext{
${ }^{51}$ PSN SAK NR. N2008/0128
} 
"Erstatning tilkjennes i scerlige tilfeller [...] at det ved en operasjon oppstår en svært sjelden og [min utheving] alvorlig komplikasjon...”. Etter ordlyden må skaden være svært sjelden (særlig uventet) og alvorlig før det skal tilkjennes erstatning etter denne regelen.

\subsection{Er særlig stor og særlig uventet to selvstendige grunnlag?}

Etter gjennomgang av flere avgjørelser vedtatt etter de midlertidige reglene kan man hevde at vilkåret til sjeldenhet og alvorlighet ble anvendt som to kumulative vilkår. Det vil si at for å få erstatning etter de midlertidige reglene måtte pasientskaden være svært sjelden og alvorlig. Spørsmålet er da om pasientskadeloven utvidet rimelighetsregelen også til å gjelde særlige uventede pasientskader.

Fra NOU 1992:6 s.77-78 reises det tvil om erstatning skal ytes ved de skadefølger som sjelden inntreffer, hvor disse ikke er vesentlige, utvalget mener dette taler for at erstatning ikke skal ytes. Det samme gjelder for skader som ikke er alvorlig, men uunngåelig og sjelden. Dette taler for at det er to kumulative vilkår.

I pasientskadeloven er det etter ordlyden to alternative vilkår, men praktiseringen av regelen er lik den som foretas etter de midlertidige reglene. I Ot.prp. nr 31 foreslår

departementet videreføring av Pasientskadenemndas praksis og utvalgets forslag. ${ }^{52}$ Regelen i lovens $\S 2$ tredje ledd synes således å være en videreføring av innarbeidet praksis i de midlertidige reglene $\S 3 \mathrm{a}$ og d. I NOU 1992:6 står det at både viktigheten av inngrepet, skadehyppighet og skadens omfang inngår ved vurderingen av om risikoen er akseptabel. Dersom skadeomfanget er uforholdsmessig stort sett i forhold til indikasjonsstilling og skaderisiko gis det erstatning.

\footnotetext{
${ }^{52}$ Ot.prp.nr. 31 (1998-99) s. 68 annen spalte.
} 
Her har vi en situasjon hvor lovens ordlyd trekker i retning av to selvstendige grunnlag, men hvor forarbeidene og praksis taler for at det er to kumulative vilkår. Man kan reise et spørsmål om ikke uttrykket "eller" burde blitt byttet ut med "og", slik at erstatning unntaksvis kan ytes ved "særlig stor og uventet skade", dersom dette var lovgivers intensjon. 


\section{Hvor går grensen for risiko som må aksepteres?}

\subsection{Innledning}

All behandling har en viss risiko for at det kan oppstå komplikasjoner. Noen skader er en følge av en kjent risiko som må aksepteres, spørsmålet er om man kan fastslå når man har trådt over grensen for når en skade kan sies å ligge utenfor den risiko en pasienten må akseptere. Ved vurderingen av om skaden er uventet så man på skadefrekvensen av den realiserte skaden. Rettspraksis har lagt seg på en streng linje for hva som ansees som uventet etter $\S 2$ tredje ledd. I Pasientskadenemndas avgjørelsen (PSN 2007 -768), ble risikoen for den inntrådte skaden satt til 0,05 -0,2\% og ble kvalifisert som uventet (se punkt 4.7.4). Når vi skal vurdere om skaden ikke kan anses som et utslag av en risiko pasienten må akseptere vil man måtte ta en helhetsvurdering hvorav grunnlidelsens art, risiko for skade, skadeomfang og sjeldenhet blir vurdert opp mot akseptabel risiko.

Arbeidsgruppens notat påpeker at undersøkelse, diagnostikk og behandling ofte innebærer en risiko for skade. De mulige skader kan være store eller små, pasienten kan bære risikoen for skade enten fordi skadene er uvesentlige eller fordi sjansen for at de skal inntreffe er liten, men det finnes en grense for hva pasienten skal måtte tåle uten erstatning. Dersom den mulige skaden er av større omfang, vil grensen for hva som anses som akseptabel risiko snevres tilsvarende inn, alvorlige skader vil oftere kunne føre til erstatning på grunn av uakseptabel risiko. Både skadens omfang og sjansen for at den vil inntreffe må sees i sammenheng med sykdommens art. ${ }^{53}$

Lødruputvalget uttaler at man i vurderingen av om risikoen er akseptabel må vurdere indikasjon for behandlingen, skadehyppighet og skadens omfang. Utvalget uttaler at $\S 3$ bokstav a tar sikte på å gi erstatning hvor skaden står i misforhold til det man fra

\footnotetext{
${ }^{53}$ Arbeidsgruppens notat s. 24
} 
viktigheten av inngrepet, sannsynligheten for at skade skulle inntre og skadens størrelse anses uakseptabel for den som rammes. ${ }^{54}$

\subsection{Akseptabel risiko sammenholdt med grunnlidelsens art}

Cauda equinadommen (Rt 1998 s. 1538) omhandler en pasient som etter en bilulykke fikk brudd i en virvel i korsryggen som medførte skade på isjiasnerven og smerter. Han fikk også en skade av de nerverøttene som kalles cauda equina. På grunn av problemer med seksualfunksjonen og økende ryggsmerter som skyldtes tranghet for nerverøttene i cauda equina, ble han operert i ryggen med sikte på å fjerne eller bedre isjiasplagene. Ved operasjonen ble nerverøtter nederst i ryggen påført skade, noe som medførte smerter i underlivet, vannlatingsforstyrrelser og forverring av seksualfunksjonen. Pasienten anførte blant annet at skaden var et resultat av en uakseptabel risiko. Risikoen for skade var anslått til cirka fem \%. Høyesterett fant at den skaden som inntraff lå i risikoens retning og fant at ansvarsbegrensingen i § 3 bokstav a, i den midlertidige ordningen kom til anvendelse. Skaden lå innenfor en risiko som pasienten må akseptere.

I den såkalte Rupturdommen (Rt 1998 s. 1336) fikk en kvinne under fødsel en total overrivning av endetarmsmuskelen. Hun ble inkontinent for avføring og fikk etter flere operasjoner utlagt tarm. A anførte at skader som skyldes en manglende helbredelse av grunnlidelsen var en risiko som ikke kunne aksepteres. Totalrupturen ble betraktet som As grunnlidelse. Høyesterett fant at skadens omfang, sykdommens art (grunntilstand) ikke var en uakseptabel risiko.

Det er ikke en pasientskade når det tilsiktede resultat ved behandlingen ikke oppnås. ${ }^{55}$ Dette stiller seg så klart annerledes dersom tilhelingen skyldes at det er benyttet inadekvat behandlingsform eller at behandlingen er utført på en inadekvat måte. Når pasienten har en

\footnotetext{
${ }^{54}$ NOU:1992 s. 39

${ }^{55}$ Arbeidsgruppens notat s. 24
} 
grunntilstand som medfører en økt risiko for komplikasjoner/skade, vil han/hun måtte bære en større risiko uten at det ytes erstatning.

\subsection{Akseptabel risiko sammenholdt med livreddende behandling}

I Ot.prp. nr 31 sies det at en risiko vil være kalkulert dersom det er nødvendig å utsette en pasient for fare for å redde liv. ${ }^{56}$ I Angiografidommen som er omtalt i punkt 4.7.7 fikk pasienten en nerveskade i høyre arm, risikoen for nerveskaden ble anslått til å ligge på cirka 5\%. Høyesterett vurderte indikasjonen for behandlingen, skadens omfang og sykdommens alvor. Det var solid indikasjon for behandlingen, når det gjaldt skadens omfang uttalte Høyesterett:

"Selv om skaden gir betydelige plager for $A$, kan jeg ikke se at selve skadeomfanget er så stort at dette alene kan danne grunnlag for erstatning, når skaden sammenholdes med den livsnødvendige behandlingen A fikk".

Ved vurderingen av om skaden inntraff på en slik måte eller var av en slik karakter at skaderisikoen kan sies å ligge utenfor hva som kan aksepteres uttalte retten:

"Det kan sies å være atypiske skader A har pådratt seg. Selv om de forekommer sjelden i kombinasjon, dreier det seg om skader som må anses for påregnelige ved hjertebehandling. Sammenholdt med den livsnødvendige hjerteoperasjonen er hans skader etter mitt syn utslag av en risiko som må aksepteres". ${ }^{57}$

Høyesterett uttalte at man i noen tilfeller må akseptere en alvorlig skade som ikke er til å unngå ved behandlingen for å redde pasientens liv. I disse tilfellene vil situasjonen som regel være den at man ikke har noe valg med hensyn til undersøkelsen eller behandlingen.

\footnotetext{
${ }^{56}$ Ot.prp. nr 31 (1998-99) s. 91, første spalte.

${ }^{57}$ Rt 2006 s. 1217 (avsnitt 44 og 46)
} 
I Sarkomdommen (Rt 2008 side 218) som er omhandlet i punkt 4.7.2 fant Høyesterett som Pasientskadenemnda, at det var en velkjent og betydelig risiko for alvorlige stråleskader ved den formen for kreftbehandling skadelidte fikk. At han mistet synet var en risiko han måtte regne med. De øvrige skadene som et delvis ødelagt strupehode, ødelagt nedre del av svelget og tap av tale var antatt som meget liten risiko, antatt sannsynligheten var anslått til å være mindre enn én prosent. Men Høyesterett kommer til at selv om risikoen er svært liten lå den innenfor det pasienten måtte akseptere. Både skadens omfang og sjansen for at den skal inntreffe ble også her vurdert opp mot sykdommens art. Pasienten hadde en livstruende kreftform hvor livreddende behandling ble satt i gang og hvor det ikke var noen reell valgmulighet for å avstå fra behandlingen. Har pasienten en alvorlig sykdom hvor livsnødvendig behandling er nødvendig, vil pasienten måtte tåle en større skade og en større risiko uten erstatning.

\subsection{Skadeomfang og uakseptabel risiko}

Dersom pasienten ikke har en livsfarlig grunnlidelse vil det ved stort skadeomfang være en grense for hva som kan anses som en akseptabel risiko. I PSN 2007-15 fant nemnda at risikoen på $0,5 \%$ lå utenfor det pasienten måtte akseptere i forhold til indikasjon for behandlingen, som i dette tilfellet var relativ og av forebyggende art.

I PSN 2007-768 var komplikasjonen sjelden og alvorlig, skadefrekvensen ble anslått til 0,05 - 0,2\%. Det er ytterst sjeldent at det oppstår så omfattende skader i tilknytning til denne type inngrepet. Nemnda finner etter en helhetsvurdering at risikoen for komplikasjoner ligger utenfor akseptabel risiko. 


\section{Tilstrekkelig informasjon}

\subsection{Innledning}

Ved anvendelse av rimelighetsregelen i pasientskadeloven $\S 2$ tredje ledd skal det legges vekt på om det er gitt tilstrekkelig informasjon. Ved vurderingen av om skaden er særlig stor eller særlig uventet blir det sentrale å trekke en grense mot en akseptabel risiko. Denne vurderingen blir i utgangspunktet objektiv, men må etter siste setning likevel vurderes i lys av hva pasienten fikk vite om risikoen. ${ }^{58}$ Det skal legges vekt på den informasjonen pasienten har fått i rimelighetsvurderingen. ${ }^{59}$

\subsection{Hvilke risikoer er det nærliggende å informere om?}

For at helsepersonell skal kunne yte helsehjelp er det et vilkår at pasienten har gitt sitt samtykke. For at samtykke skal være gyldig må pasienten ha fătt nødvendig informasjon om sin helsetilstand og innhold i helsehjelpen jfr. pasientrettighetsloven $\S 4$-1. Informasjonen skal gi pasienten et forsvarlig beslutningsgrunnlag.

\subsection{Anvendelsesområdet for momentet tilstrekkelig informasjon}

I Nervesvulstdommen og Cauda equinadommen kom Høyesterett til at det foreligger en vid plikt til å gi informasjon, særlig om risikoer som det er overveiende sannsynlighet for vil inntre, samt risikofrekvenser helt ned til fem prosent der det er snakk om risiko for en alvorlig skade. Etter forarbeidene til pasientrettighetsloven er informasjonsplikten strukket helt ned til en skadefrekvens på en prosent. Selv om man ikke kan trekke en klar grense for når det foreligger en informasjonssvikt, vil dette måtte bero på en skjønnsvurdering der grunnlidelsens art, indikasjon for behandlingen, skadens omfang og om det var reelle behandlingsalternativer vurderes. Innskytspunktet til $\S 2$ tredje ledd siste punktum vil derfor være der risikoen for

\footnotetext{
${ }^{58}$ Norsk Lovkommentar, Pasientskadeloven, Ørnulf Rasmussen, side 8.

${ }^{59}$ Ot. prp. nr. 31 (1998-99) s. 91, annen spalte.
} 
skade/komplikasjoner ikke omfattes av sviktbestemmelsen. ${ }^{60}$ I disse tilfellene vil betydningen av informasjonen kunne tillegges vekt, dersom skaden er stor og uventet.

\subsection{Betydningen av tilstrekkelig informasjon etter $\S 2$ tredje ledd}

For å vurdere betydningen av dette momentet er det nødvendig å se på hvordan domstolen og Pasientskadenemnda betrakter og vektlegger momentet om det er gitt tilstrekkelig informasjon på forhånd. Borgarting lagmannsrett har i en sak vurdert spørsmålet om hva som er å anse som tilstrekkelig informasjon etter pasientskadeloven $\S 2$ tredje ledd. Dommen er omtalt under punkt 4.9.3 Saken gjaldt en 50 år gammel kvinne som ble påført en nerveskade ved en hofteoperasjon. ${ }^{61}$ Skaden førte til nedsatt gangfunksjon i venstre ben, såkalt dropfot.

Lagmannsretten fant ikke at den manglende informasjonen om risiko for nerveskade var av avgjørende betydning for vurderingen av om skaden i dette tilfellet kan anses som særlig uventet. Retten pekte blant annet på at selv om kvinnen ikke var gjort kjent med den konkrete risikoen for nerveskade, var hun generelt kjent med at det forelå en risiko for komplikasjoner ved en operasjon av det omfang det var tale om her, og hun var også gjort kjent med enkelte av de komplikasjoner som kunne oppstå.

\subsubsection{Praktiseringen av momentet}

Etter lovens ordlyden skal det legges vekt på om det er gitt tilstrekkelig informasjon på forhånd. En "skal-regel" er den sterkeste varianten av lovregler, en naturlig språklig forståelse av "skal" er at det påbudt å se hen til dette momentet. ${ }^{62}$ Vil man da som rettsanvender kunne se bort fra dette momentet i helhetsvurderingen?

\footnotetext{
${ }^{60}$ Se vedlegg 1 , Illustrasjoner.

${ }^{61}$ LB 2007/16311

${ }^{62}$ Eivind Kolflaath, språk og argumentasjon s. 169-172
} 
Etter gjennomgang av noen nemndsavgjørelser hvor $\S 2$ tredje ledd er drøftet, kan det se ut til at momentet om det er gitt tilstrekkelig informasjon sjeldent nevnes, men at det går inn i vurderingen av om det foreligger informasjonssvikt etter første ledd bokstav a. Noen nemndavgjørelser vil benyttes for å belyse hvordan dette momentet blir praktisert.

I saken om kvinne som fikk en tarmperforasjon etter en endetarmsundersøkelse (PSN 2006-463), uttaler nemnda under helhetsvurderingen at den legger "... til grunn at pasienten ikke var gitt informasjon om risiko og mulige komplikasjoner". Selv om nemnda ikke angir betydningen av dette momentet, kan det se ut til at det har vært en viktig faktor ettersom de ikke drøftet informasjonssvikt i 2 første ledd bokstav a. Pasienten fikk her medhold etter $\$ 2$ tredje ledd.

PSN 2006-432 omhandler en pasient som fikk skade på stemmebåndsnerven etter operasjon. Pasienten anførte at han ikke fikk informasjon i forkant av inngrepet om at denne type komplikasjon kunne oppstå. Nemnda drøfter først om det foreligger svikt ved ytelsen av helsehjelpen. Deretter går nemnda over til å se på om $\S 2$ tredje ledd kommer til anvendelse. I den forbindelse drøfter de skadefrekvens, skadens omfang og sjeldenhet og grunnsykdommens alvor. Nemnda konkluderer med at det foreligger en risiko som må aksepteres, det kommer ikke frem av drøftelsen at de har tatt med betydningen av anførselen om at det ikke er gitt tilstrekkelig informasjon, men derimot drøfter de avslutningsvis om det foreligger informasjonssvikt etter $\S 2$ første ledd bokstav a.

I saken om kvinnen som anførte nerveskade etter ryggoperasjon (PSN 2004-546), uttalte kvinnen at hun ikke hadde mottatt tilstrekkelig informasjon forut for inngrepet. Her vurderer nemnda først sviktregelen i $\S 2$ første ledd bokstav a, så drøfter de $\S 2$ tredje ledd hvor de tar opp indikasjonen, pasientens grunntilstand, skadens omfang og sjeldenhet, de nevner heller ikke her kvinnens anførsel om at det ikke er gitt tilstrekkelig informasjon. Til slutt drøfter de om det foreligger informasjonssvikt etter $\S 2$ første ledd bokstav a. 
Betydningen av momentet tilstrekkelig informasjon er også utelatt i drøftelsen om kvinnen som etter fjerning av eggledere fikk en blødning (PSN 2009-0375). Kvinnen anførte at hun ikke ville ha gjenomgått inngrepet dersom hun på forhånd var klar over konsekvensene. I denne saken drøfter nemnda både behandlings- og informasjonssvikt i vurderingen av § 2 første ledd bokstav a. De går så over til å se på § 2 tredje ledd, her drøfter de skadens art og omfang, indikasjon og komplikasjonshyppighet, de kommer så til at det er en risiko som må aksepteres.

Pasienten som ble operert for coiling av aneurismen i hjernen (PSN 2007-15) fikk medhold etter $\S 2$ tredje ledd. I denne saken ble det også anført at pasienten ikke ble informert om risiko for komplikasjoner før inngrepet. Her drøfter ikke nemnda $\S 2$ første ledd, da de legger til grunn at tredje ledd kommer til anvendelse. Nemnda ser på indikasjonen, skadefrekvens, skadens omfang og de nevner at det er noe usikkert hva pasienten på forhånd ble informert om, men det sies ikke noe om betydningen av dette momentet.

\subsection{Oppsummering av tilstrekkelig informasjon}

Utgangspunktet for drøftelsen av om det er gitt tilstrekkelig informasjon i tredje ledd er at det ikke foreligger informasjonssvikt. Om det foreligger informasjonssvikt må avgjøres konkret $\mathrm{i}$ hvert enkelt tilfelle, men man kan finne en viss veiledning $\mathrm{i}$ høyesterettspraksis og forarbeidene til pasientrettighetsloven. Betydningen av om det er gitt tilstrekkelig informasjon på forhånd ser ut til å være begrenset. I noen tilfeller har det vært et tilleggsargument der det har foreligget en relativ indikasjon, hvor risikoen for den aktuelle skade var meget lav og skadeomfanget stort, hvis det i tillegg er unnlatt å gi informasjon om skadevirkningen på forhånd, kan det se ut til at dette argumentet har vært "tunga på vektskåla" som trekker i retning av medhold etter rimelighetsregelen. I motsatt tilfelle vil det ved god indikasjon, liten risiko og ingen reelle valgmuligheter for andre behandlingsformer ikke være et moment av betydning.

I avgjørelsene nevnt ovenfor har man ikke skilt ut betydningen av om det er gitt tilstrekkelig informasjon i helhetsvurderingen, dette på tross av at det kommer klart frem av 
lovteksten at det skal legges vekt på. Det virker også noe merkelig at man ikke belyser dette momentet i de tilfeller pasienten anfører at de ikke har mottatt tilstrekkelig informasjon. Dette kan tolkes på to måter, enten at momentet ikke er av betydning for avgjørelsen av saken eller at de ikke helt klarer å se forskjellen mellom drøftelsen av informasjonssvikt i § 2 første ledd bokstav a og momentet "tilstrekkelig informasjon" i tredje ledd. Hvis betydningen av momentet her er tolket riktig, kan det reises et spørsmål om lovens ordlyd bør endres. 


\section{Avsluttende betraktninger}

Pasientskadeloven fikk en annen lovstruktur enn den midlertidige ordningen med pasientskadeerstatning, men lovgiver hadde ingen intensjoner om realitetsendring hva gjaldt hovedregelen om sviktansvar. Som jeg har nevnt innledningsvis i kapittel 4.3 ble det praktisert en rimelighetsregel i den midlertidige ordningen, dette er også stadfestet gjennom Høyesterett- og nemndspraksis. Dette innebærer at praksis som foreligger etter de midlertidige reglene fortsatt er relevant og må tillegges betydning. Pasientskadenemnda og domstolene har holdt fast ved den langvarige og konsistente praksisen som knytter seg til rimelighetsregelen.

\section{Bør sentrale momenter komme til uttrykk i lovteksten?}

Det er noen momenter som går igjen ved drøftelsen av om $\S 2$ tredje ledd kommer til anvendelse. De sentrale momentene er indikasjon, grunnlidelsens alvor, skadens omfang og sjeldenhet. Disse momentene kommer inn i hvert "ledd" i drøftelsen av om pasientskaden er: særlig stor, særlig uventet, og om hvem som er nærmest til å bære risikoen. Disse momentene ble også betegnet som de sentrale momenter i NOU 1992:6. ${ }^{63}$

En lovtekst bør inneholde momenter som er av betydning og som tillegges stor vekt.

\section{Er særlig uventet et selvstendig grunnlag etter pasientskadeloven?}

Det kan i lys av praktiseringen av regelen se ut til at skaden også må være av et visst omfang og alvorlighet for at rimelighetsregelen skal komme til anvendelse. Det fremkommer ikke noe i forarbeidene til pasientskadeloven som trekker i retning av at man ønsket å utvide rimelighetsregelen i pasientskadeloven til også å omfatte de kun uventede skadene, forarbeidene taler heller for at erstatning unntaksvis kan ytes ved alvorlig og sjeldne skader. Årsaken til at den endelige ordlyden ble slik den ble står ubesvart, men det kan reises spørsmål ved om det mer er uttrykk for en tilfeldighet enn et bevisst valg.

\footnotetext{
${ }^{63}$ NOU 1992: 6 s. 39.
} 


\section{Skal eller bor momentet -tilstrekkelig informasjon ha betydning?}

I $§ 2$ tredje ledd siste setning, spesifiseres at det skal legges vekt på om det er gitt tilstrekkelig informasjon på forhånd, dette momentet ser ut til å ha en meget begrenset vekt, men har på tross av dette kommet til uttrykk i lovteksten, i motsetning til andre sentrale momenter som indikasjon, grunntilstand, skadens omfang og sjeldenhet. Av den praksisen som er gjenomgått her, er det kun et fåtall av avgjørelser som har tatt dette momentet med i drøftelsen av rimelighetsregelen, på tross av at pasienten anfører at det ikke er gitt tilstrekkelig informasjon på forhånd. Etter mitt syn virker det forvirrende at lovgiver har angitt at det skal legges vekt på om det er gitt tilstrekkelig informasjon, men hvor det er fraværende i praktiseringen av rimelighetsregelen.

\section{Bor droftelsen av rimelighetsregelen harmoniseres med lovens struktur?}

Det har i lang tid blitt innarbeidet en praksis på hvordan man angriper en problemstilling av denne art etter den midlertidige ordningen. Drøftelsene etter denne regelen tar utgangspunkt i den lovtekniske oppbygningen av $\S 3$ a, hvor spørsmålet var om skaden var en følge av en risiko som er kjent og som ut fra den medisinske kunnskapen på skadetidspunktet må aksepteres. Vil det være riktig å bygge opp drøftelsen på samme måte når spørsmålet løses etter pasientskadeloven $\S 2$ tredje ledd? Etter pasientskadeloven vil spørsmålet være om pasientskaden er kvalifisert som særlig stor eller særlig uventet og som ikke kan ansees som en risiko som pasienten må akseptere. Selv om resultatet ikke vil endres, vil det være mer en mer pedagogisk tilnærming og følge lov strukturen.

\section{Fungerer rimelighetsregelen etter sin hensikt?}

Rimelighetsregelen er streng, det er en høy terskel for å få erstatning etter denne regelen. For de få som får erstatning etter denne rimelighetsregelen/sikkerhetsventilen, vil regelen nå sitt formål. For mange vil nok regelen oppfattes som for streng, sammenligner vi oss med Danmark hvor ca 33\% av klagene får medhold etter den danske rimelighetsregelen, får kun 3\% medhold etter den samme regelen i Norge. Man kan reise et spørsmål om regelen når sitt formål med å fange opp de tilfeller hvor det vil virke støtende på rettsfølelsen ved å ikke tilkjenne erstatning når den er så streng. 


\section{Kilde- og Litteraturliste}

\section{Kilder}

Arbeidsgruppens notat

Erstatning for pasientskader 1987.

NOU 1992:6

Erstatning ved pasientskader/Lødruputvalget

Ot.prp. nr. 12 (1998-99)

Lov om pasientrettigheter

Ot.prp.nr. 31 (1998-1999)

Om lov om erstatning ved pasientskader

Ot.prp.Nr103 (2005-2006)

Om lov om endringer i lov 15.juni 2001 nr.53

(pasientskadeloven)

\section{Litteratur}

Asbjørn Kjønstad, Helserett 1. Utgave, 1 opplag 2005.

Gyldendal Akademiske.

ISBN 82-05-31112-9.

Asbjørn Kjønstad: Erstatningsretten i utvikling. Universitetsforlaget 2003 ISBN: 82-15-00388.

Aslak Syse, Reidun Førde, Olav Helge Førde (red): Medisinske feil, Gyldendal Akademiske 2000. ISBN 82-417-1140-9.

Peter Lødrup: Lærebok i erstatningsrett, 5 utgave. Gyldendals Akademiske. ISBN 82-05-34748-4.

Ø rnulf Rasmussen: Norsk Lovkommentar Pasientskadeloven 2001,Gyldendal Rettsdata. 
Per Kåre Herredsvela: Norsk Lovnøkkel, Pasientskadeerstatning (Regler for midlertidig ordning med pasientskadeerstatning), Ad Notam Gyldendal. ISBN 82417-0554-9.

Stein Rognlien: Pasientskadeerstatning, Juridisk Forlag 1995. ISBN 82-7513-033-6

De første 10 årene, I anledning af Patientforsikringens 10 års jubilæum i 2002. Patientforsikringen september 2002.

Afgørelser og praksis gennem 10 år. En samling afgørelser og artikler fra Patientforsikringens virke gennem 10 år, Patientforsikringen september 2002. ISBN 87-989122-0-8.

Eivind Kolflaath, Språk og argumentasjon-med eksempler fra juss, 2 opplag 2007, Fagbokforlaget. ISBN 978-82-450-0074-0.

Jan Storvik: Erstatning ved feildiagnose- en kommentar. TfE Nr. 1-2/2006 årgang 3. Gyldendal Akademiske. ISSN: 1503-6782.

Felix Lous, Høyesterett og ankeutvalgets praksis i pasientskadesaker, TtE Nr. 4/2009 årgang 6. Gyldendal Akademiske. ISSN: 1503-6782.

Asbjørn Kjønstad: Reelle hensyn som rettskilde. Festtidsskrift til Fleischer. Universitetsforlaget 2006. ISBN 82-15-00960-3.

Nina Reinersen: Ny lov om pasientskadeerstatning [sitert januar 2010].

Nettadresse: dunn.no Tidsskrift for Erstatningsrett 2004, Nr 02/03/ny lov om pasientskadeerstatning 
Rolf Gunnar Jørstad: Den nye pasientskadeloven, særlig om offentlig helsetjeneste[sitert januar 2010]. Nettadresse: idunn.no Tidsskrift for Erstatningsrett 2004 Nr 02/03 Den nye pasientskadeloven, særlig om offentlige helsetjenester

\section{Dommer}

Rt. 1993 s. 1169 (Nervesvulstdommen)

Rt. 1998 s.1336 (overrivning av endetarmsmuskel under fødsel)

Rt. 1998 s. 1538 (Cauda equina-dommen)

Rt 2006 s. 1217 (Angiografidommen)

Rt. 2008 s. 218 (Sarkomdommen)

Oslo Tingrett, avsagt 16.11.2009, saksnummer 09-064490TVI-OTIR/01

\section{Nemndspraksis}

PSN 2004 s. 546

PSN 2005 s. 619

PSN 2005 s. 689

PSN 2006 s. 89

PSN 2006 s. 328

PSN 2006 s. 432

PSN 2006 s. 463

PSN 2007 s. 15

PSN 2007 s. 253

PSN 2007 s. 768

PSN Saksnummer N2007/0920 


\section{9 figurer}

Illustrasjoner

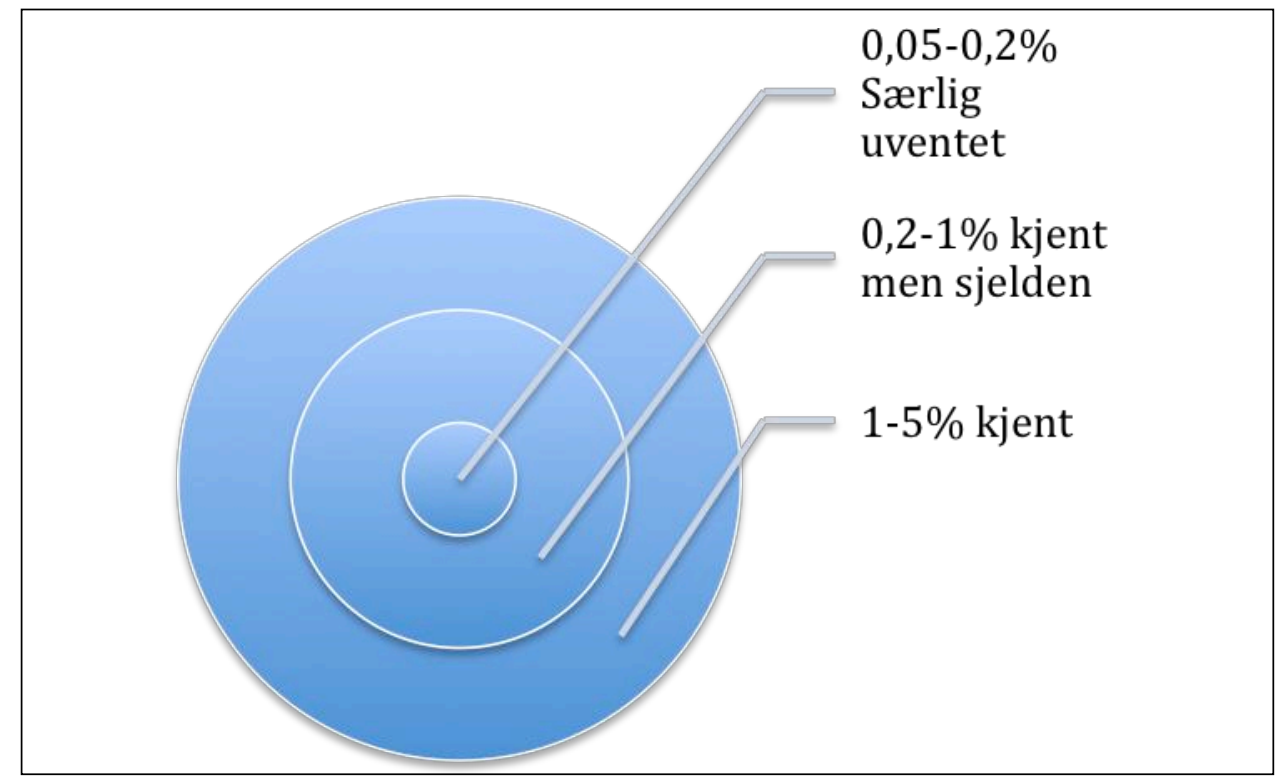

Figur 1, Hva som anses som særlig uventet etter § 2(3). 


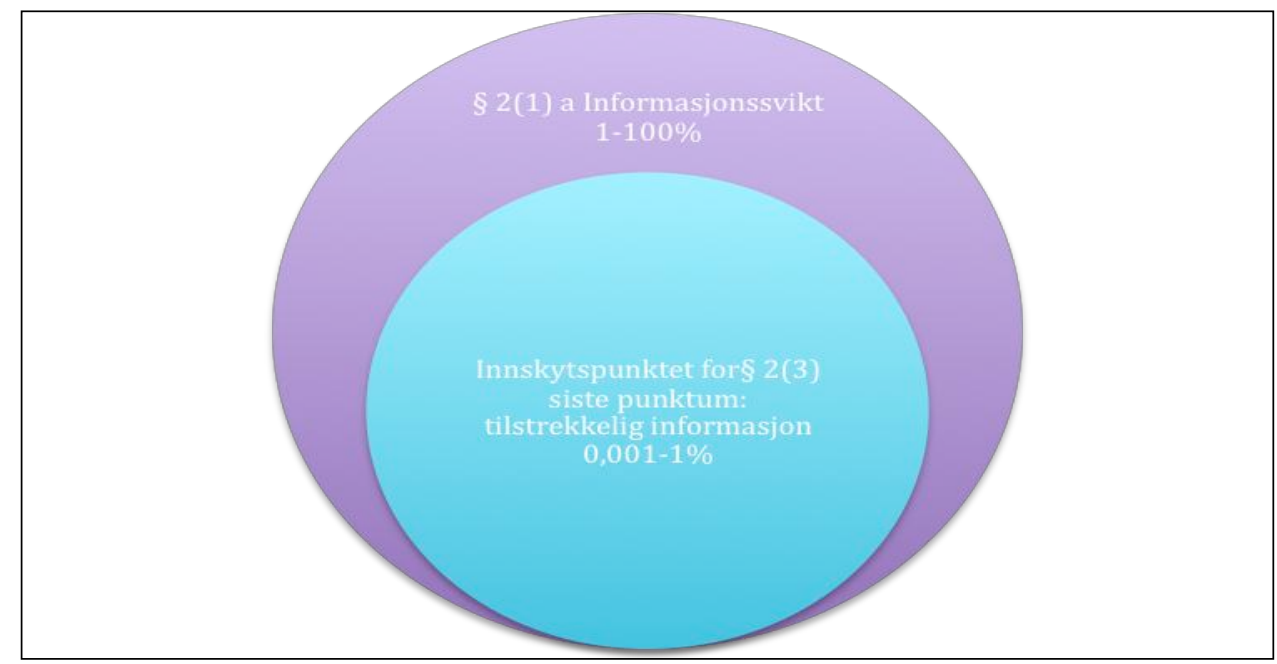

Figur 2, anvendelsesområde for § 2(3) siste punktum. 
